\title{
Historia de la esclavitud africana en el Perú desde la Conquista hasta la Abolición
}

\author{
Maribel Arrelucea*
}

Resumen Este artículo pretende reflexionar sobre la llegada de los esclavos al Perú, sus vidas cotidianas en los diferentes lugares donde fueron llevados, la riqueza de sus aportes culturales, además de las diferentes formas de enfrentar la esclavitud: desde la pasividad más absoluta hasta la rebeldía frontal. Sin caer en juicios de valor, romanticismos ni estrechez cultural, creo que el Sesquicentenario de la abolición de la esclavitud en el Perú debe servir fundamentalmente para aprender del pasado y preocuparse por el futuro de la población afroperuana.

Palabras Clave: Esclavas, castigos, cimarrones, palenque, bandoleros, abolición.
Abstract
This article refers to the arriving of slaves to Peru, their daily live in the different places where they lived and where they were carried, the wealth of their cultural contribution, and the different ways to confront slavery: from complete passivity to open rebelliousness. Without impassioned and cultural limits, I think that the Sesquicentennial of the abolition of the slavery in Peru, would be an opportunity to learn more from the past and to think about the future of afro-peruvian people.

Keywords $=$ Slaves, punish, fugitive slaves, palenque, bandoleers, abolition .

\footnotetext{
* Profesora de la Universidad Nacional Mayor de San Marcos.
} 


\section{Los primeros esclavos en la Conquista}

Cuando las huestes españolas conquistaron América, la esclavitud era una institución que formaba parte de la economía de España desde el dominio romano, continuó durante la Edad Media, sufrió una crisis cuando los turcos tomaron Constantinopla, pero se fortaleció durante la Reconquista. Los esclavos estaban en todos lados, en chacras, talleres, casas y, sobre todo, en puertos como Sevilla y Cádiz.

La incorporación de algunos esclavos en las primeras expediciones no es casual pues muchos tenían amplia experiencia marina. Eran frecuentemente empleados por los navegantes portugueses, genoveses y españoles en los viajes de exploración, y algunos eran propiedad de pilotos, maestres o armadores de barcos.

Durante la conquista del Tahuantinsuyo, los españoles trajeron sus esclavos como auxiliares militares y sirvientes. En 1534, Pedro de Alvarado partió desde Guatemala hacia las tierras del sur llevando consigo 200 esclavos; aunque fracasó, esos esclavos fueron vendidos a otros soldados que sí llegaron al Tahuantinsuyo. Parece que el entusiasmo por conquistar las tierras sureñas provocó un éxodo de españoles y esclavos. Así, un informe de 1535 indica que 600 españoles y 400 esclavos habían dejado Panamá rumbo al Perú. ${ }^{1}$

En la Capitulación de Toledo (26 de julio de 1529) se da licencia a Pizarro para traer 50 esclavos, de los cuales un tercio eran hembras. Los esclavos estaban al lado de sus amos conquistadores sirviéndoles como soldados, auxiliares, sirvientes y amantes.

Si buscamos información sobre esclavos en las crónicas encontraremos apenas algunas menciones en acciones pero casi nunca sus nombres. El maestro artillero de la primera expedición de Pizarro y Almagro llevó consigo un africano asistente. En Pueblo Quemado, Almagro fue herido gravemente, cayó a tierra y fue salvado por un esclavo. En la isla del Gallo no pasaron trece, el decimocuarto fue un esclavo, llevado posteriormente a Tumbes donde fue bañado diligentemente por los naturales para quitarle el color.

Diego de Almagro organizó la funesta expedición a Chile en 1535 con aproximadamente 150 esclavos. Uno de ellos fue Juan Valiente, esclavo fugitivo de México, quien luego acompañaría a Pedro de Valdivia, ya como soldado libre, con sus propias armas y caballo. Con mayor fortuna, obtuvo una concesión de tierras y el privilegio de emplear indios.

Juan José Vega ha comprobado la presencia de esclavos y libertos luchando directamente contra las tropas incaicas identificando algunos: fueron esclavos los que llevaron el oro del Cuzco para el rescate en Cajamarca, varios esclavos cayeron defendiendo Sacsayhuamán, otros defendiendo Lima durante el sitio de Manco Inca, muchos más derramaron sus sangres en diversas batallas como Parcos y Pampas contra un general de Manco Inca. Pero los esclavos y libertos no sólo fueron soldados, también contribuyeron a controlar a los indígenas, ejerciendo de capataces con látigo en la mano.

También estuvieron presentes en las guerras civiles: fue un negro quien de un certero golpe cortó la cabeza al primer virrey del Perú, don Blasco Núñez de Vela. Asimismo, después de la batalla de Chupas, el derrotado ejército de Almagro El Mozo, incluía mil esclavos. Gonzalo Pizarro tenía cerca de 600 esclavos en la batalla de Añaquito. Al año siguiente, después de la batalla de Huarina, Gonzalo Pizarro envió esclavos para registrar el campo de batalla y ejecutar a los enemigos heridos. El bando realista también empleó esclavos, la mayoría de ellos en actividades especializadas como la manufactura de arcabuces, espadas y lanzas. $^{2}$

Entre 1553 y 1554, Hernández Girón se levantó contra la Corona e hizo algo inaudito

\footnotetext{
${ }^{1}$ Bowser, Frederick. El esclavo africano en el Perú colonial. Madrid: Siglo XXI, 1977, pág. 23.
} 
para su época: ofreció la libertad a todos los esclavos que se unieran a su causa. Rápidamente formó un batallón con 150 esclavos comandado por un negro llamado Juan, quien guió sus huestes exitosamente en la batalla de Chuquinga; pero en la batalla de Pucará, la mayoría de ellos desertó y se dedicó al saqueo precipitando la derrota. Su oponente, Gómez Arias Dávila, vecino de Huánuco y leal al rey, también llevó a sus propios esclavos como auxiliares.

Junto con los conquistadores también llegaron algunas esclavas negras, indígenas y moriscas que actuaban como sus fieles amantes, otras pasaron como botín de guerra al poder de los incas. Juan José Vega afirma que Manco Inca poseía varias esclavas en su serrallo de Vitcos, una de ellas le advirtió que uno de los españoles refugiados pretendía asesinarlo. ${ }^{3}$ Margarita, esclava de Almagro en Panamá, lo acompañó en la conquista del Tahuantinsuyo, y continuó a su lado durante su encarcelamiento y ejecución. Antes de su muerte, Almagro le otorgó la libertad. Posteriormente, Margarita adoptó el apellido de su amo, fundó una capellanía en el convento de La Merced en el Cuzco y durante las guerras civiles prestó dinero a los realistas para derrotar a los alzados.

Lucas Martínez Vegazo llegó con Pizarro en el tercer viaje, luchó en las guerras de conquista, obtuvo una encomienda, participó en las guerras civiles, perdió y recuperó su encomienda; y en todas estas peripecias lo acompañó su esclava morisca Beatriz, con quien procreó una hija. Posteriormente, el encomendero liberó a la esclava, le dio su apellido y contribuyó con la crianza de la hija, enviándoles ropa y otros artículos a Arequipa, lugar donde ellas fijaron su residencia. ${ }^{4}$
La política de la Corona frente a la esclavitud fue vacilante. En un primer momento prohibió la entrada a la isla La Española de esclavos de otras religiones -como judíos, moros y convertidos-, dejando el pase libre sólo a aquellos que eran cristianos y nacidos entre cristianos. ${ }^{5}$ Es posible que los reyes intentaran evitar el ingreso de ideas religiosas diferentes, pero las necesidades reales de los conquistadores pudieron más.

Uno de los más graves problemas generado por la conquista y colonización fue el exterminio de poblaciones enteras. Esto se solucionó, de alguna manera, incorporando sirvientes de diversas castas: mestizos, indígenas, negros, mulatos, así como alquilas, yanaconas, peones y esclavos africanos. La esclavitud se insertó en un mosaico de formas, por ello perdió algunas características propias de Europa y se adecuó al sistema americano.

Los esclavos fueron distribuidos de acuerdo a las necesidades de la nueva economía colonial. Fueron llevados masivamente a los lugares donde faltaba mano de obra para trabajar en las plantaciones, puertos y algunas minas. En estos centros la esclavitud fue masiva y de primera importancia, como en Cuba y otras islas del Caribe, algunas regiones de México (Oaxaca, Veracruz, Guerrero, Campeche, Tabasco, Jalisco, Zacatecas) y las costas colombianas. Esto también se presentó en las capitales, por ser centros políticos y comerciales muy activos, como Caracas, Buenos Aires, Valparaíso, Lima y México. En contraste, en otros lugares donde abundaban indígenas no fue necesario importarlos en grandes cantidades. En estos lugares fueron empleados mayoritariamente como artesanos, jornaleros, peones de haciendas o para el servicio doméstico.

\footnotetext{
${ }^{2}$ Lockhart, James. El mundo hispanoperuano, 1532-1560. México: FCE, 1981.

${ }^{3}$ Vega, Juan José. "Negros contra incas". Historia y cultura, 24, 2001.

${ }^{4}$ Lockhart, James. Los de Cajamarca. Un estudio social y biográfico de los primeros conquistadores del Perú. Lima: Milla Batres, 1986, vol. II, pp. 155-158.

${ }^{5}$ Las Instrucciones a Nicolás de Ovando, 3 de septiembre de 1501, es el primer documento donde se regula la presencia de esclavos en América. A pesar de las restricciones iniciales, arribaron a América y Perú esclavos y esclavas moriscos.
} 
Lo mismo sucedió en el Perú. Muchos pensaron que el esclavo africano por ser más resistente podría reemplazar al indio en labores más pesadas, como en las minas. De esa manera poblaron con esclavos negros ciudades andinas como Jauja, Huánuco, Cuzco, Cerro de Pasco, Puno y Huancavelica, pero ante las enfermedades y muertes prefirieron enviarlos a la costa donde el clima era más benigno para ellos. Así, los esclavos fueron destinados a las ciudades, especialmente Lima, y a las haciendas de la costa ubicadas en Piura, Lambayeque, Chicama, Supe, Pativilca, Saña, Cañete, Ica, Chincha, Pisco y Moquegua.

\section{La trata negrera}

Las rutas negreras se trazaron tomando como referencia el puerto de embarque de esclavos y el de llegada a las colonias, formándose un triángulo entre Europa, África y América. Este tráfico estaba reglamentado al igual que el monopolio comercial. Los negreros debían pagar sus impuestos de ingreso, el almojarifazgo, al igual que cualquier otra mercancía. De acuerdo a la legislación, los negreros introducían esclavos africanos a Cartagena de Indias, Veracruz y algunas veces Buenos Aires, además podían dirigirse hacia algún otro puerto como Cuba, Maracaibo, Jamaica (antes del dominio ingles), La Española (Santo Domingo), Guayaquil, Callao, Valparaíso, etc. Los arrieros llevaban esclavos a diversas ciudades en el interior del continente como Huancavelica, Cuzco, Puno, el Alto Perú, Tucumán, Córdova, Salta, Jujuy y Buenos Aires. Esta ruta complicada y extensa solo encareció los precios y alentó el contrabando vía Buenos Aires-Potosí y Buenos AiresValparaíso-Arica. ${ }^{6}$

Los esclavos llegaban al Perú desde Panamá, un puerto pequeño, poco profundo, con modestas casas de madera que subsistía gracias a los galeones y las flotas. La travesía era peligrosa e insegura por el clima, el excesivo calor, las lluvias torrenciales, la geografía misma y las continuas huidas de los esclavos. La navegación hacia Perú duraba tres semanas. En ocasiones, los mercaderes desembarcaban en Paita, donde aprovechaban para vender algunos esclavos, bajaban en mulas a Trujillo, lugar donde también efectuaban ventas, y continuaban hasta llegar a Lima.

La mayoría de los esclavos llegaban enfermos a Lima. Desnudos, mal alimentados y entumecidos, eran portadores de enfermedades como el sarampión, la viruela, la tifoidea, la fiebre amarilla o el paludismo. Otros llegaban mutilados, con heridas, abscesos y defectos físicos.

Para evitar contagios, recién en el siglo XVII, el virrey Marqués de Guadalcazar dispuso que los esclavos permanecieran en cuarentena de observación en una chacra cercana a Lima; después eran conducidos a la ciudad encadenados, de dos en dos, para venderlos. Posteriormente, el mismo virrey ordenó la construcción de unos barracones en San Lázaro donde permanecían alojados. Iguales precauciones se tomaban en todas las ciudades.

Es muy difícil calcular el número exacto de esclavos que se trajeron a las colonias hispanas. Para el caso peruano, Mellafe $(1973)^{7}$ hizo cálculos tomando en cuenta el tonelaje de los barcos negreros, las licencias y contratos. De esta manera, pudo afirmar que entre 1551 y 1640 entraron 1,207 barcos negreros con 350,000 esclavos de ambos sexos. Para 1773 calcula una cantidad de 516,114 esclavos. Así, para todo el periodo colonial no le parece exagerado hablar de tres millones de esclavos.

Por otro lado, en el Perú de fines del siglo XVI había aproximadamente veinte mil esclavos, incrementándose a 40,336 censados en 1791 . Durante el Protectorado llegaban a 41,228 y fueron disminuyendo a medida que la trata negrera era atacada por Inglaterra, tanto es así

\footnotetext{
${ }^{6}$ Peralta, Germán. Los mecanismos del comercio negrero. Lima: Kuntur, 1990.

${ }^{7}$ Mellafe, Rolando. Breve historia de la esclavitud en América Latina. México: SepSetentas, 1973.
} 
Son cifras aproximadas pues también ingresaban esclavos de contrabando en números muy altos pero sin dejar huellas aparentes para rastrearlos.

\section{Precios de los esclavos}

La Corona no reguló los precios de los esclavos en sus dominios. Eran los negreros quienes determinaban el valor de cada esclavo. Según Germán Peralta ${ }^{8}$ los precios fluctuaban teniendo en cuenta tres factores. En primer lugar, la nacionalidad del esclavo; así, los que provenían de algunas regiones como Cabo Verde eran más apreciados que los de Angola y Guinea. El espacio geográfico de las transacciones fue otro factor importante pues los precios eran más bajos en los puertos atlánticos y mucho más elevados en las zonas del Pacífico o en el interior de los Andes. El precio de un esclavo en Lima era un 80 a 90\% más elevado que en Cartagena. Finalmente, el tercer factor era el fraude pues a mayor fraude menor probabilidad por parte de la Corona de mantener precios altos. El fraude alentó una rápida venta y a precios razonables, mientras que la trata oficial siempre mantuvo sus precios altos y exorbitantes.

Para el siglo XVI Peralta calculó el precio promedio de un esclavo en las colonias españolas en 350 pesos de 8 reales. A fines del siglo XVI, un esclavo en buenas condiciones costaba 204 pesos en Buenos Aires mientras que en Lima no pasaba de 400 pesos. Para el siglo XVIII los precios fueron similares y sólo se incrementaban cuando se trataba de un esclavo con especialización laboral como sastre, zapatero, tejedor, carpintero, pintor, etc. También cuando se ofertaba una esclava embarazada o joven, bonita y de piel clara quienes llegaban a cotizarse entre 500 y 600 pesos. ${ }^{9}$

En algunas cartas de compra y venta se emplea un lenguaje muy particular para tasar un

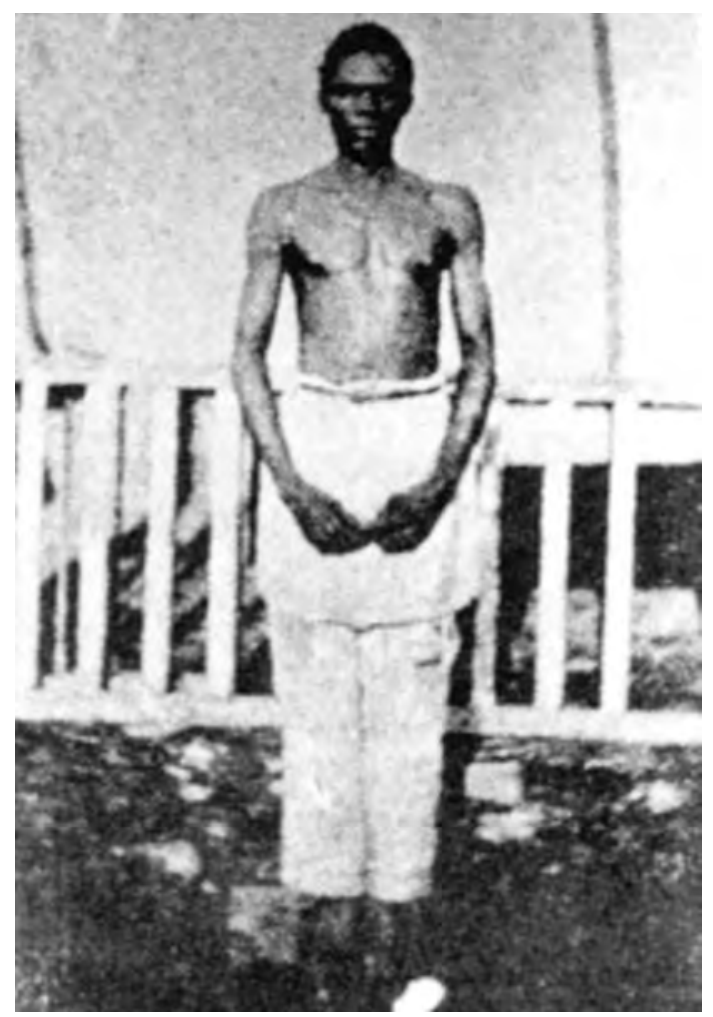

Bozal negro recién llegado a Cuba, 1860. Fuente: Dumont "Antropología".

hasta 7 años de edad, muleque hasta los de 12 años y mulecón a todos aquellos que no pasaban de 16 años. Igualmente, aparece el término bozal para identificar a los recién llegados de África, ladino para los esclavos nacidos en África pero que ya habían adoptado la lengua y las costumbres occidentales; los criollos quienes eran los esclavos nacidos en América, y finalmente los horros quienes eran los esclavos manumitidos (libres).

Las cartas de compra y venta especificaban puntualmente las tachas de los esclavos, es decir, los defectos y enfermedades. De no hacerlo, el nuevo propietario, sintiéndose estafado, podía exigir la redibitoria, la devolución del dinero. Veamos algunos ejemplos.

\footnotetext{
${ }^{8}$ Peralta, Ibid.

${ }^{9}$ Arrelucea, Maribel. "Conducta social de los esclavos de Lima, a fines del siglo XVIII". Tesis, 1999, Lima: UNMSM. Mis investigaciones coinciden con las de Alejandro Reyes, La esclavitud en Lima. Lima: UNMSM, 1985.
} 
En 1766, doña María Eusebia Sarmiento vendió a don Antonio de la Breña, cura de Guamanga, una esclava llamada Plácida, de 18 años, con su pequeño hijo especificando que era una mulatillo casi blanco, ambos en 500 pesos. Al finalizar afirma que "no asegura que Plácida sea borracha, ladrona y cimarrona", además padecía de gota coral, lamparones, vómito verde y se le quitaba el habla. Si hubiera sido otra esclava, tal vez el precio sería más bajo, tomando en cuenta las tachas, pero como Plácida era una mulata casi blanca, el cura no hizo mayores reparos. ${ }^{10}$ Francisco Bernal, vecino de Guayaquil, vendió un esclavo en Lima estando huido aclarando que "estaba preso en el Callao por un hurto que hizo en Guayaquil".11

Raúl Adanaqué afirma que para vender un esclavo se colocaban avisos en las pulperías, tambos o chinganas. Uno de esos avisos anunciaba: "La persona que quisiese a la negra Isabel Sánchez Baca, con una hija de cinco a seis años y un negrito de siete meses, su precio por los tres es de ochocientos cincuenta pesos. Puede acudir a su amo en la inteligencia que este es el último precio" ${ }^{12}$ De lo contrario, el amo entregaba un aviso al mismo esclavo y lo enviaba a la calle para ofrecerse él mismo. Esto último parece haber sido frecuente hasta bien entrado el siglo XIX.

Es interesante entonces observar las peculiaridades de la esclavitud peruana colonial y decimonónica donde los amos dejaban a sus esclavos buscar y elegir, si se podía, a sus futuros propietarios, otorgándoles márgenes de tiempo libre.

Pero para vender un esclavo rápidamente, éste debía presentar la menor cantidad de tachas. El problema era cuando el esclavo era un conocido cimarrón, alborotador, bandolero o ladrón. En esos casos los llevaban a las panaderías donde trabajaban encadenados y hasta allí llegaban compradores que después los vendían a mayor precio en haciendas más lejanas. Cuando

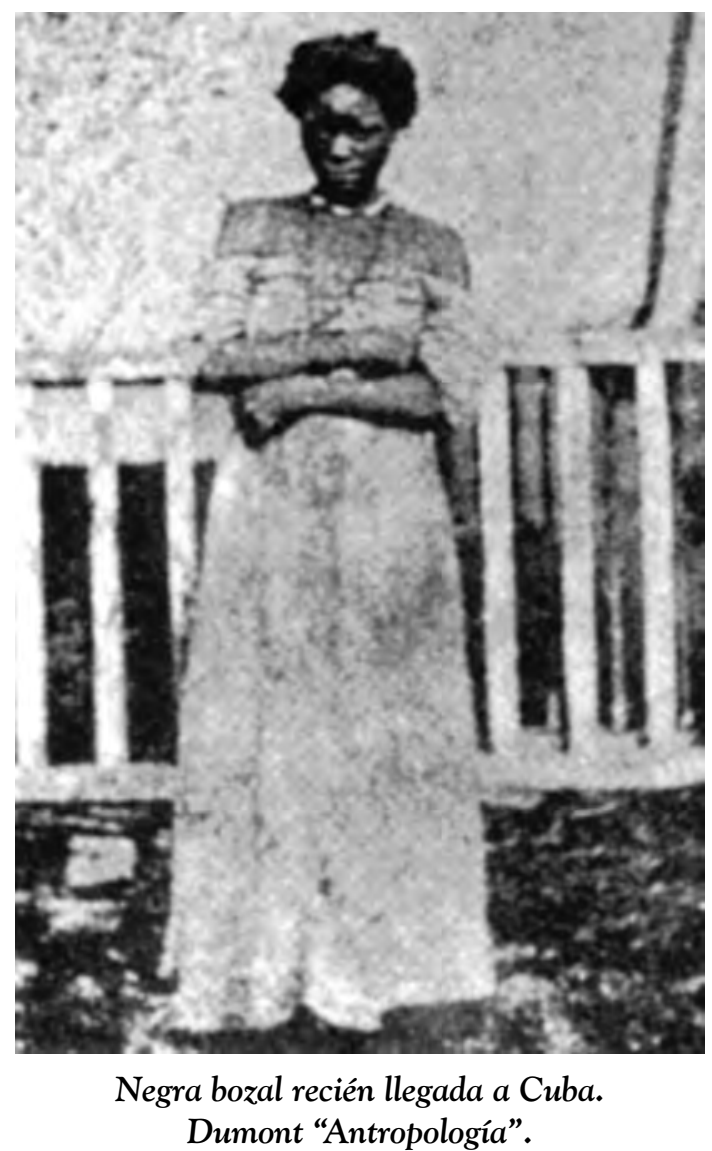

se trataba de venta colectiva, el propietario recurría a un subastador quien ofrecía los esclavos en pleno mercado y posteriormente cobraba una comisión por su trabajo.

\section{El palmeo y la carimba}

El palmeo consistía en la medición de cada esclavo. El asentista podía pagar los impuestos correspondientes cuando el esclavo era considerado pieza de Indias, esto después del palmeo: debía tener un mínimo de 7 palmos de estatura, aproximadamente $1,90 \mathrm{~m}$. También incluía un examen físico y un cálculo de la edad que se hacía revisando los dientes, ojos y manos del esclavo. Si el esclavo no alcanzaba la estatura, o

\footnotetext{
${ }^{10}$ Archivo General de la Nación, Notario Angulo, protocolo 45.

${ }^{11}$ Archivo General de la Nación, Notario Bustinza, protocolo 154, 1765.

${ }^{12}$ Adanaqué, Raúl. "La esclavitud en Lima, siglo XVIII". Historia y cultura, 24, 2001, pag. 28.
} 
tenía defectos físicos (ojos nublados, manco, cojo, sordo, mudo, etc.), su precio disminuía notablemente.

Después venía la carimba, es decir la marca del dueño del esclavo. Los grandes asentistas que traían esclavos de África solían colocarles su marca con un hierro candente en algún lugar visible del cuerpo: la mejilla, el hombro, la espalda, el brazo, la pierna, etc. Pero no eran los únicos, el Rey también mandaba colocar una R rematada con una corona a todos los esclavos que entraban a sus reinos; igualmente los amos preferían colocar su inicial en sus esclavos para identificarlos confacilidad en caso de fuga.

De esa manera, un esclavo podía exhibir varias marcas en su cuerpo. Algunas personas alzaron su voz de protesta ante la carimba como el arzobispo Santo Toribio de Mogrovejo, quien exigió su abolición en el Concilio Limense pero esto recién se haría mediante una Real Cédula dictada en ElEscorial, el 4 de noviembre de 1784.

\section{Salud y enfermedad}

Los esclavos sufrían de diversas enfermedades. Las más comunes eran: bubones, llagas y úlceras en el cuerpo, ojos nublados, tuertos, cojos, mancos, algunos no tenían los dedos completos, gangrena, la gota coral (enfermos del corazón), epilepsia, fiebres, abscesos, sarna, enfermedades venéreas, ceguera, sarampión, sordera, asma, dolores de cabeza, tercianas, vómitos, problemas estomacales, diarreas, incontinencia urinaria, etc. Algunos propietarios declaraban que sus esclavos gozaban de buena salud, pese a que presentaban síntomas, que no bloqueaban su capacidad laboral, como arrojar sangre por la boca; con el tiempo podía declararse la tuberculosis, bastante frecuente entre los esclavos. ${ }^{13}$

En las cartas de compra y venta se registraba siempre esta información. En 1765, don Juan Antonio Garay, conocido hacendado limeño, compró "21 piezas bozales sin bautizar, de varias castas y edades... seis piezas con adiciones, un negro con una nube en el ojo, una negra tuerta que le falta varios dientes, un negro manco de la mano derecha, otro con la rodilla fuera de lugar y otro con dos clavos de buba, uno de cada pie, otro mal del corazón y gota coral". El precio de cada esclavo fue de 450 pesos y el de las esclavas 470 , especificando que se hace una rebaja de 50 pesos por cada esclavo enfermo. ${ }^{14}$ En 1783 , Juliana Ladrón de Guevara vendió a Teodoro Zapata en 500 pesos una esclava de 24 años, que tenía "la campanilla caída y al hablar respira por las narices". ${ }^{15}$

Cuando un esclavo se enfermaba era obligación del propietario pagarle la asistencia médica y el tratamiento. Por lo general, los amos procuraban mantenerlos sanos, pero otros preferían evitar el gasto abandonándolos a su suerte en los hospitales o vendiéndolos rápidamente silenciando la enfermedad. Las mujeres embarazadas no recibían una atención especial, trabajaban igual, seguían pagando su jornal laborando en las chacras, vendiendo mercaderías, etc. Después del parto, el propietario podía permitirle descansar, algunos pagaban los gastos, reforzaban la alimentación y compraban lo necesario para el bebé, porque estaban enriqueciendo su propiedad, pero otros amos preferían dejar esa responsabilidad al padre biológico.

La muerte era un asunto importante para los esclavos. Durante el siglo XVI sus cadáveres eran arrojados a los basurales que se amontonaban en las calles y caminos, no tenía derecho a una sepultura en terreno sagrado. Posteriormente, fueron admitidos en las catacumbas, al interior de las iglesias. Pero el funeral y el entierro eran costosos, por loque debían ser cubiertos por el propietario, sin embrago algunos se desatendían del asunto y preferían otorgarles la libertad. Entonces, los responsables eran los familiares del difunto. Algunos de ellos, miembros de cofradías, sentían alivio pues esta institución cubría los gastos de sus

\footnotetext{
${ }^{13}$ Adanaqué, Raúl. "Condiciones de vida de los esclavos en el Perú”. El Peruano, Lima, jueves 28 de Marzo de 1991.

${ }^{14}$ Archivo General de la Nación, Notario Joseph de Aizcorbe, protocolo 11.

${ }^{15}$ Citado por Raúl Adanaqué, ibid. Pág. 33.
} 
funerales, pero la gran mayoría debía ingeniárselas para lograr enterrar a sus seres queridos.

\section{Castas de esclavos}

Según El Mercurio Peruano, a fines del siglo XVIII, los esclavos estaban agrupados en diez castas: terranovos, lucumíes, mandingas, cambundas, caravelíes, cangoes, chalas, huarochiríes, congos y misangos. Varios investigadores han coincidido que muchas de esas denominaciones corresponden a nombres de puertos y factorías donde se celebraban los contratos y asientos pero no a sus verdaderas naciones étnicas. ${ }^{16}$ Fernando Romero afirma que existían más de ochenta grupos diferentes, todos ellos procedentes del norte de las costas occidentales africanas. Por su parte, Jean Tardieu, ha identificado varias castas analizando los registros notariales y los libros parroquiales; identificó muchos grupos étnicos venidos de tres grandes áreas africanas: Guinea, Sao Thomé y la zona bantú.

De Guinea procedían esclavos llamados de Cabo Verde, Ríos de Guinea, Cazangas, Bagnoun, Balantas, Folupos, Biohos, Zapes, Cocolíes, Mandingas y los Jolufos o Gelofes. De Sao Thomé (entre Togo y Nigeria) procedían los Branes o Abrons, los Gandjas, los Minas, Popós o Ararás, Terranovos o Gouns, Lucumíes o Yorubas y los Caravalíes. La zona bantú se extendía hacia el Sur y el África central; de allí procedían los Biafras o Fan, Anchicos o Batekes, Mosangas, Angus, Luanda y Mozambiques.

La casta formaba parte de la identidad del individuo, en un esclavo era como el apellido. Existían nombres como Juan Congo, Francisco Lucumí, María Arará, etc. Otros esclavos llevaban el apellido del primer amo: Pedro Garagay, José Alvarado, etc. Otros usaban el apellido del amo pero alterado, el título del Marqués de Valle Umbrosio por ejemplo, pasó a ser apellido levemente transformado en Ballumbrosio.

\section{Lalegislación}

Durante la Colonia, las normas legales estaban contenidas en diferentes corpus jurídicos como las Leyes de Toro, las Leyes de Indias y la Recopilación de las Leyes de Indias. Según la primera, la relación esclavista debía ser como la de un padre con su hijo. El amo debía proteger al esclavo dándole alimentos, vivienda, vestimenta, atención médica y medicinas. Además solo se le debía castigar ante una causa justificada: desobediencia, insubordinación, mentiras, evasión o cimarronaje, torpeza en el trabajo, etc.

Los derechos del propietario eran casi absolutos. El esclavo, por el hecho de serlo, no tenía gobierno sobre su persona y su personalidad, también perdía el dominio sobre su trabajo y sobre las rentas generadas. Además, esto se extendía hasta el infinito porque los hijos de una esclava nacían esclavos, pero si ella recibía la libertad graciosa (manumisión) sus hijos nacidos después eran libres.

A pesar de considerar al esclavo como una mercancía, la legislación colonial les reconoció algunos derechos como la integridad física: si el propietario sometía al esclavo a la sevicia (excesivos castigos), éste podía acudir a los tribunales para ser vendido a otro amo, y eventualmente, si el castigo había sido brutal, podía esperar la manumisión. Los propietarios estaban prohibidos de obligar a sus esclavas a mantener relaciones sexuales, de lo contrario, ellas obtenían la libertad.

La legislación también permitía la manumisión. Un esclavo podía acceder a la libertad por dos caminos legales: la primera fue la libertad graciosa, es decir, el propietario decidía liberar a su esclavo por diferentes motivos (generalmente cuando la muerte se aproximaba, el amo redactaba su testamento recordando a los esclavos fieles). El problema en este tipo de libertad es que casi siempre era dada con obligaciones: se otor-

\footnotetext{
${ }^{16}$ Ver los numerosos artículos de Raúl Adanaqué aparecidos en El Peruano (1991), La Mañana (1993) y Época (1993). También Fernando Romero. Quimba, fá, malambo, ñeque. Afronegrerismos en el Perú. Lima: IEP, 1980; y Jean Tardieu. "Evolución del reclutamiento de los negros bozales en la arquidiócesis de Lima, siglo XVI-XVII". Hisla, vol. XIII, XIV, 1989.
} 
gaba después de la muerte del amo, pero algunos estipulaban que debían servir a otra persona, ir al convento, trabajar con un maestro artesano, mandar misas a nombre del amo, portarse según los preceptos de la iglesia, etc.

En 1766, el padre Diego Manuel de Bermúdez manumitió a Joseph, su mujer Josepha y el hijo de ambos "por el amor con que me han servido" pero estipulaba que gozarían de la libertad después de su muerte. Algunos esclavos se impacientaban, perdían el temor y el respeto por el amo, como sucedió con Mariano Jacinto, mulato de 20 años a quien su amo decidió otorgarle la libertad "por servirlo con amor" pero al margen, en una escritura posterior, se anula la carta de libertad graciosa por "inobediencia, infidelidad y otros excesos que ha cometidoy faltaderespeto". ${ }^{17}$

También podía ser mediante la automanumisión, es decir, cuando el esclavo pagaba por su cabeza al contado o por cuotas, amortiguando el total. Esto último fue frecuente, pues la mayoría de cartas notariales consignan el precio del esclavo y a continuación se añade "y no se puede vender en más".

Existe una preocupación marcada en las leyes coloniales para controlar a los esclavos. Estaba prohibido que circulen pasadas las diez de la noche, portar armas o un simple cuchillo de cocina, conversar en grupo en las pulperías y chinganas, jugar a los dados y naipes, salir de la casa sin permiso, etc. Con estas normas se intentaba evitar que se junten para intercambiar confidencias sobre las costumbres, negocios, dinero y joyas de sus amos.

Las esclavas no podían lucir joyas de oro o piedras preciosas como las que tenían las mujeres españolas y criollas. En el caso de mujeres negras casadas con español solo debían usar zarcillos de oro muy sencillos. Tampoco debían vestir ropas confeccionadas con telas finas, guantes o zapatos de raso. ${ }^{18}$
En general, los delitos cometidos por los esclavos se castigaban con los azotes públicos (entre 50 y 200 según el delito), la horca en la plaza pública, en ocasiones el descuartizamientoy algunas veces con el destierro. Muchos eran enviados a presidios en Cuba, Cartagena y Filipinas, lugares tan lejanos que las probabilidades de retornar eran escasas. Chile también fue uno de los lugares que receptó delincuentes, pues era una colonia pobre que atraía pocos inmigrantes y, además, muy peligrosa por los continuos alzamientos de los araucanos.

Otros eran condenados a las galeras, lo que en la practica no se cumplía porque no existían en el virreinato, así que los esclavos realizaban trabajos forzados en los puertos y ciudades. Se encargaban de limpiar acequias, arreglar puentes, tajamares y caminos, picar piedra en las canteras, etc. ${ }^{19}$ Resulta interesante imaginar el desenvolvimiento cotidiano de una ciudad con calles céntricas donde era posible observar a los presos arreglando las acequias, los esclavos encadenados preparando pan, ver la plaza llena de vendedores y gente paseando, en un costado el rollo destinado a azotar a los presos y muy cerca, la horca. En los caminos, a veces, se encontraban largas picas con brazos, manos, pies y cabezas de cimarrones y ladrones famosos.

Durante la República, algunos Presidentes dictaron decretos complementarios sobre los esclavos pero las leyes coloniales se mantuvieron plenamente vigentes en la regulación de los deberes de los esclavos y, sobretodo, del control de sus conductas.

En las ciudades los panaderos siguieron azotando por encargo a los esclavos díscolos y haciéndolos trabajar bajo las peores condiciones. En las chacras y haciendas, los caporales administraban "justicia" con diferentes castigos como: los azotes, "la paila" (el esclavo era encerrado debajo de los calderos hirvientes), "la escalera" (se amarraban las manos y los pies del

\footnotetext{
${ }^{17}$ Archivo General de la Nación, Notario Alejandro Cueto, protocolo 198.

${ }^{18}$ Leyes extraídas de Las Siete Partidas, Las Leyes de Indias y La Recopilación de las Leyes de Indias.

${ }^{19}$ Arrelucea, Maribel, 1999: pág. 56.
} 
esclavo, por los extremos para dar azotes) "la colgada" (el esclavo era colocado frente a un árbol o madero y colgado de las manos para azotarlo), el cepo, entre otros.

\section{El trabajo esclavo desde el siglo XVI hasta el XIX}

\section{Trabajo esclavista en el medio rural}

Desde Piura hasta Moquegua, durante toda la colonia y hasta bien entrado el siglo XIX, existían grandes haciendas dedicadas al cultivo de caña de azúcar, trigo, cebada, legumbres, vid, alfalfa, olivos, etc. Otras también tenían actividades transformativas en las cuales se elaboraba pan de azúcar, aguardiente, chancaca, melao y aceite de oliva. Algunas haciendas pertenecían a particulares, otras a la Iglesia y sus diferentes órdenes religiosas, entre las cuales destacaba la Compañía de Jesús, expulsada en el siglo XVIII. En estas grandes haciendas empleaban esclavos en grandes números, aunque en el Perú no alcanzaron cifras como en Brasil, pero aquí empleaban entre 150 y 300 esclavos por hacienda. Una de esas fue San Francisco de Borja de Tumán, en Trujillo, propiedad de los jesuitas, donde se llegaron a emplear entre 110 y 179 esclavos. En el año de su expulsión, poseían 217 esclavos. ${ }^{20}$

Los jesuitas $^{21}$ eran muy disciplinados en las labores agrícolas. La reconstrucción del ritmo laboral en una de sus haciendas nos dará una imagen del trabajo rural. El amanecer era anunciado por el tañido del Ángelus, momento donde se tomaban los primeros alimentos, formaban cuadrillas y trabajaban toda la mañana tomando un descanso al mediodía para el almuerzo. El mayordomo decía quiénes iban a lampear, champear, regar, pampear, etc. El caporal, ayudado por sus auxiliares, llevaba a los esclavos para que trabajen en las plantaciones de caña, viñales o algodonales; también se encargaba de vigilarlos, y castigarlos. En el caso de la caña de azúcar, el trabajo era más pesado porque varios hombres debían cortar y transportar la caña hasta los depósitos, luego venía lo más extenuante: accionar manualmente los molinos, triturar la caña, extraer el mosto, colocarlo en unas pailas y toneles para hervirlo, y preparar los panes de azúcar.

Finalizada la zafra, los esclavos debían limpiar el campo, eliminar los desechos, quemarlos, reparar los cercos y los instrumentos de labranza. También se encargaban de roturar los suelos usando los arados de madera o de hierro jalados por bueyes o mulas. Todo este trabajo era realizado por hombres y mujeres, jóvenes y adultos, sin distinción. Los más viejos, las mujeres en estado avanzado de gestación y los niños se encargaban de cuidar las semillas y frutos de los pájaros rapaces, acarrear la caña, cocinar, matar aves, limpiar la casa hacienda, etc.

Además, la hacienda contaba con esclavos especializados en algún oficio como sastrería, carpintería, herrería, zapatería, albañilería, barbería, platería, panadería, etc., Quienes, a su vez, tenían sus propios ayudantes. A estos esclavos se le prohibía ostentar el título de maestro de oficio, sólopodían llegar a ser oficiales.

El trabajo era agobiante, pero los jesuitas, de manera astuta, otorgaban descansos de hora en hora. Algunas veces repartían raciones de tabaco como premio a los esclavos más diestros, también algunos domingos ofrecían espectáculos de títeres para distraer a sus trabajadores. La comida era buena, consistía en raciones de pan, frijol, maíz, harina, zapallo y carne. Además, una vez al año se les entregaba ropa hecha de bayeta, jergas, pañetes, sayales y cordellatas. Los hombres recibían un juego de pantalón y camisa, ropa interior y cotón, mientras que las mujeres recibían faldellín, rebozo, camisa y ropa interior.

\footnotetext{
${ }^{20}$ Cajavilca, Luis. La esclavitud en la hacienda San Francisco de Borja de Tumán, ss. XVI-XVII, Lima: UNMSM, 1997.

${ }^{21}$ Las haciendas jesuitas han sido estudiadas por Macera, Pablo. Trabajos de Historia. Lima: INC, 1977. También ver Kapsoli, Wilfredo. Sublevaciones de esclavos en el Perú. Siglo XVIII. Lima: Univ. Ricardo Palma, 1976.
} 
Las parturientas eran tratadas de manera especial pues dejaban de trabajar durante ocho días y eran atendidas por una esclava, les daban vino, gallinas, velas, telas adicionales para pañales y la ropa del recién nacido. Además, todos los esclavos recibían una parcela pequeña dentro de la hacienda destinada al cultivo de legumbres, conocida también como conuco. También tenían permiso para criar sus propios cerdos y aves de corral, ya sea para el consumo familiar o para la venta. De esta manera los jesuitas les daban mejor alimentación y trato que en otras haciendas, pero no se trataba de un gesto paternal porque solo intentaban conservar a sus esclavos como fuerza de trabajo.

Pero también existían propiedades rurales medianas y pequeñas dedicadas al cultivo de hortalizas, alfalfa, granos, etc., las que empleaban esclavos en menor número, como en la chacra Puente (Lima)donde tenían 29 esclavos o en Pando donde eran 40. Sean grandes propiedades o pequeñas, casi todas entregaban pequeñas parcelas a sus esclavos para que cultiven hortalizas y cuiden aves de corral y cerdos. De esta manera, los mismos esclavos eran responsables de aumentar su propia dieta y procurarse ingresos extras con la venta de sus productos. En todas estas propiedades construían la casa del dueño o arrendatario, galpones para los esclavos, además del infaltable cuarto de castigo con cepos y grilletes.

La hacienda del capitán Pedro de Montoya, por ejemplo, es la típica unidad en el siglo XVII. Poseía una viña de más de 200 hectáreas que producía 6500 botijas de vino al año, tenía 80 esclavos de diferentes castas y nacionalidades, la mayoría hombres, sólo 5 mujeres. También poseía un ingenio azucarero o trapiche para producir melaza y azúcar de pan, y plantaciones de caña. Dentro de la hacienda había 500 cabras y ovejas, 36 mulas, un molino de granos, un huerto con árboles frutales, una forja de herrero con el equipo completo, más un africano herrero. Al otro lado 400 olivos que producían 200 jarras de aceitunas y 20 botijas de aceite, 20 mil sauces para cubrir las necesidades de madera y un campo sembrado de trigo que producía cerca de 40 metros cúbicos al año. Poseía una casa hacienda en el centro y dos barracones destinados a los esclavos, uno de hombres y otro de mujeres. ${ }^{22}$

En el siglo XIX, el ritmo de trabajo esclavo siguió igual: los propietarios mantenían a sus esclavos trabajando largas horas, viviendo en galpones, comiendo lo mismo, castigándolos con el cepo, azotes y cadenas. En 1825 se publicó el Reglamento Interior de las Haciendas de la Costa, elaborado por una comisión de hacendados para ordenar el trabajo agrícola y esclavo en especial en el marco de la campaña inglesa contra la esclavitud y la disminución de esclavos traídos de África. Según este Reglamento, los esclavos debían trabajar desde las seis de la mañana hasta el mediodía, luego tomar un descanso para continuar desde las dos de la tarde hasta las seis. Después podrían retirarse a comer, rezar y descansar. A las nueve, todos debían estar encerrados en sus galpones.

Pero para las haciendas cañeras el horario era diferente. En el verano el trabajo empezaba a las cuatro de la mañana y finalizaba a las seis de la tarde mientras que en invierno empezaba a las cinco de la mañana. Por supuesto que muchos hacendados y arrendatarios no respetaban estas normas y obligaban a sus esclavos a jornadas más agotadoras. Pero los esclavos, sabiendo el contenido del Reglamento, se quejaban. Así sucedió en 1841, cuando los esclavos de la hacienda Copacabana, en Lima, acudieron ante el Defensor de Menores para quejarse que "debiéndose principiar las labores desde las seis de la mañana hasta las doce del día y desde las dos de la tarde hasta las seis, los principian antes de las seis y en la tarde concluyen a las siete". 23

\footnotetext{
${ }^{22}$ Citado en Bowser, Frederick, 1977: pag. 134.

${ }^{23}$ AGN, Causas Civiles, Legajo 271, 1841. Ver también Aguirre, Carlos. Los esclavos de Lima y la desintegración de la esclavitud en Lima. Lima: PUCP, 1993.
} 


\section{Trabajo esclavista en las ciudades}

Los esclavos, desde los inicios de la Colonia hasta el siglo XIX, fueron empleados en varios ámbitos: para el servicio doméstico, las actividades transformativas y los llamados servicios menores.

\section{Servicio domésticos}

En las ciudades grandes, especialmente en Lima, algunos esclavos domésticos eran usados como signo de riqueza y ostentación de privilegios. Los altos dignatarios civiles y eclesiásticos, tanto de la Colonia como de la República, se desplazaban por las calles con un séquito de esclavos y subordinados, mientras las señoras se hacían acompañar de pequeños esclavos para ir a la misa o de visita. En las casonas se desempeñaban como amas de llaves, costureras, cocheros, cocineros, jardineros, lavanderas, acompañantes, etc. Los burócratas menores, los comerciantes, los artesanos y hasta personas de pocos recursos, incluyendo indios y libertos, seguían el ejemplo: compraban esclavos para el servicio doméstico pero también para jornal. Durante las mañanas los esclavos se ocupaban de las tareas de la casa: comprar, cocinar, limpiar, lavar la ropa, zurcir, cuidar niños y enfermos, moler los granos, etc. Después salían a la calle a ganar un jornal.

La ama de leche fue la figura típica de la esclavitud doméstica colonial y decimonónica por la extendida costumbre de las mujeres de negarse a dar de lactar a sus hijos, aduciendo deformaciones físicas, dolores de cabeza, etc. Además se creía que la leche de las negras era muy nutritiva, por eso los médicos aconsejaban tomarla para alimentar a los bebés delicados o prematuros y curar enfermedades como la debilidad y la tuberculosis (para esta última enfermedad los médicos recetaban leche de negra o de burra). Durante el siglo XIX, y después de la abolición, la leche de las negras continuaba siendo percibida como la mejor y más nutritiva para los bebés. Las ofertas se hacían en la calle, como era tradicional, y también en los periódicos donde se colocaban avisos como el siguiente, aparecido en El Comercio de Lima el 31 de julio de 1856 :

\section{¡OJO AL AVISO! \\ Se ofrece ama de leche entera sana, de buenas costumbres y con garantías, en la fresquería de la plazuela de San Lázaro, darán razón.}

Las personas de la elite compraban esclavas que estaban dando de lactar para que se encarguen de sus hijos. De esa manera la ama de leche pasaba a ser la "mamá de leche" mientras sus hijos y los del amo se llamaban entre sí "hermanos de leche". Algunas lograban tener un lugar prominente en la familia, mejoraban su alimentación y vestuario, además la libertad podía ser un premio a la fidelidad, como consta en muchas cartas de manumisión.

Esto fue visto por algunos ilustrados como una relajación de la esclavitud en el ámbito doméstico y denunciado en El Mercurio Peruano en dos artículos. En el primero, titulado "Apólogo histórico sobre la corrupción de las colonias romanas de África", el autor establece una analogía entre las mujeres romanas y las limeñas, quienes dejaron la alimentación y educación de sus hijos en manos de las esclavas, para llegar a la conclusión que la decadencia de la sociedad romana fue producto de la relajación moral y la disolución de las jerarquías entre las castas. ${ }^{24}$

El segundo artículo, titulado "Amas de leche. Segunda carta de Filomantes sobre la educación", advierte claramente el peligro del creciente poder doméstico de las amas de leche y repite el discurso moral: los esclavos contaminan la inocencia de los niños que amamantan, enseñando sus bailes y costumbres indecentes. El discurso ilustrado centra su preocupación en la educación de los

\footnotetext{
${ }^{24}$ El Mercurio Peruano, 16 de enero de 1791. Lima: Biblioteca Nacional, edición facsimilar, 1964. Un buen análisis de estos artículos en Velázquez, Marcel. El revés del marfil. Nacionalidad, etnicidad, modernidad y género en la literatura peruana. Lima: UNFV, 2002.
} 


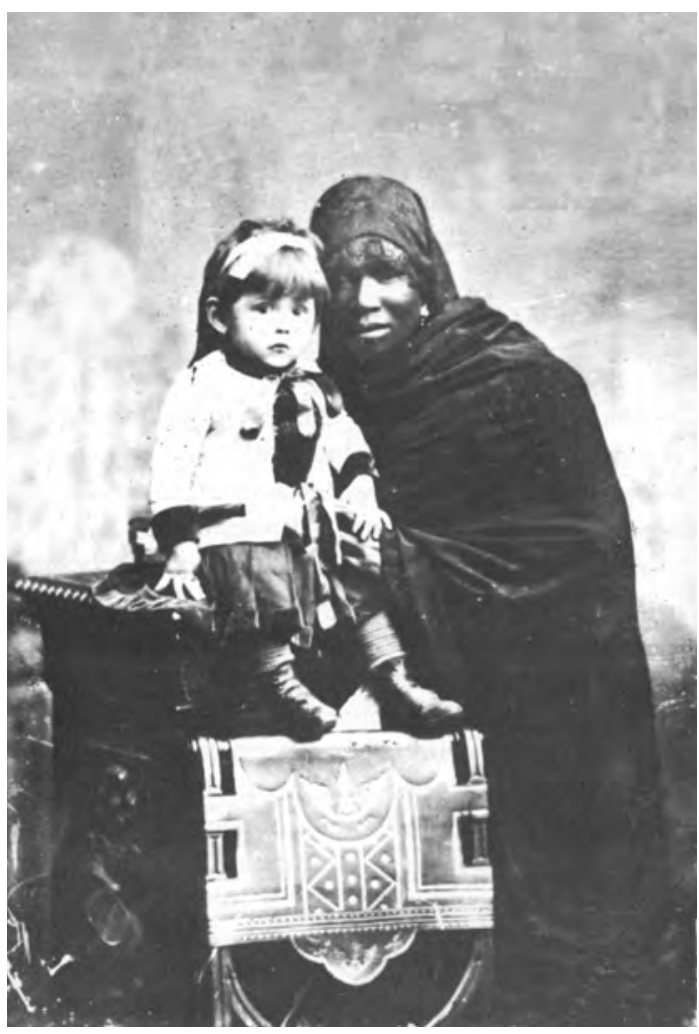

Ama de leche con su niño. Fuente: Archivo fotográfico E. Courret.

niños y el control de los subordinados domésticos: mujeres y esclavos. ${ }^{25}$

Pero no todas las esclavas tenían una vida privilegiada pues la mayoría prefería contratarlas a jornal porque se reducían las relaciones afectivas, se evitaba mantener a la esclava, darle sus alimentos, vestirla, etc.

Otro ámbito de la esclavitud doméstica se desplegó entre las paredes de los conventos. Muchas señoritas de la elite tomaban los votos llevando consigo a sus esclavas quienes se encargaban de servirlas igual que en la casa. Ellas cocinaban, lavaban la ropa, limpiaban la celda, compraban en las pulperías cercanas, llevaban recados y noticias. No sólo trabajaban para sus amas, también servían de conexión con el mundo exterior. Más de una monja enviaba a sus esclavas a ganar un jornal en la calle; algunas vendiendo los dulces preparados dentro del convento, otras buscaban cualquier empleo eventual. A pesar de haber hecho votos de pobreza y renunciar a sus propiedades, muchas monjas compraban y vendían esclavos, algunos para su servicio personal o para jornal. Pero no sólo las monjas poseían esclavos, también los eclesiásticos (sacerdotes, monjes, predicadores) y con los mismos fines. Ejemplos hay muchos: en 1645 el cura don Francisco de Alcántara compró por 400 pesos una esclava bozal sin bautizar, cuya edad era de 20 años. ${ }^{26}$ En 1791, el cura doctrinero del pueblo de Corongo compró a Valeriana Lorente exclusivamente para su servicio personal. $^{27}$

Las paredes de la casa, el monasterio y la hacienda son testigos de otro aspecto de la esclavitud: las relaciones sexuales y afectivas entre amos y esclavos. Éstas eran casi públicas y toleradas por todos, sustentadas en buena parte en estereotipos raciales y sexuales. En la sociedad colonial y decimonónica se creía que toda mujer era libertina, propensa a los placeres sexuales, por eso había necesidad de controlarla, educarla. Si así se pensaba de la mujer en general, sobre la esclava se tejió el mito de mujer devoradora, sensual, lujuriosa, disponible y peligrosamente tentadora. Por eso, según la percepción general, carecía de honor y virtud. Sin embargo, en los documentos se leen reclamos de esclavas sobre la conservación de su honor y honra. Estos estereotipos buscaban controlar la conducta de las mujeres, y en el caso de las esclavas las sujetaba más aún al dominio del propietario, además de librar a éste de posibles culpas por tener relaciones con un subordinado.

\footnotetext{
${ }^{25}$ ElMercurio Peruano, 27 de enero de 1791. Lima: Biblioteca Nacional, edición facsimilar, 1964.

${ }^{26}$ Archivo General de la Nación, Protocolos Notariales, Méndez, Protocolo 198, 1645.

${ }^{27}$ Archivo General de la Nación, Real Audiencia, Causas civiles, Legajo 235, Cuaderno 2019.
} 


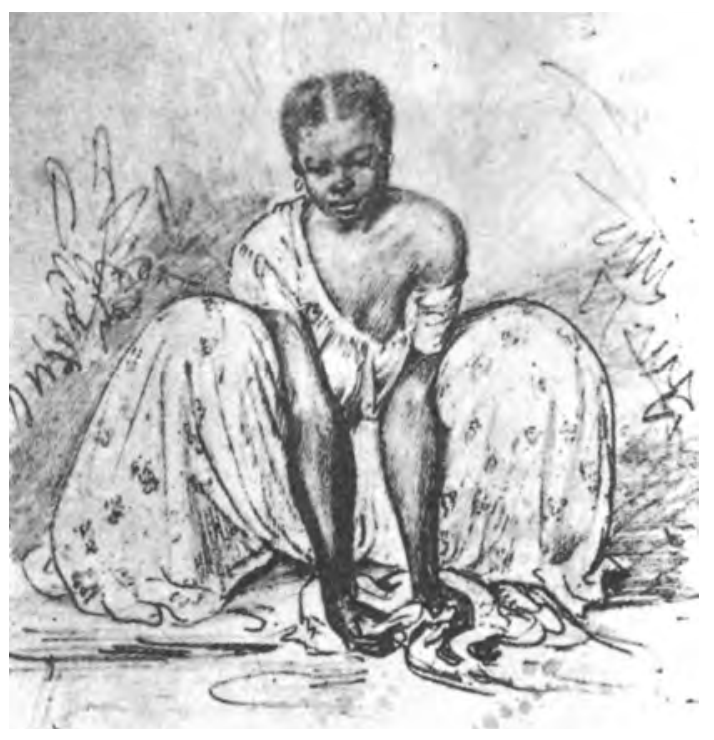

En la sociedad peruana existió el estereotipo generalizado de la mujer negra sensual y libertina que se reflejó en los grabados y pinturas como esta de Mauricio Rugendas.

Los amos podían apelar a su derecho de propietario para usar el cuerpo de la esclava, frente a lo cual ellas tenían varias opciones: el rechazo, la resignación, la conciliación o los tribunales. Lo último no fue frecuente, era difícil para una esclava probar el delito, reunir testigos honorables que confirmen la denuncia, porque cuando se presentaban como testigos a otros esclavos, sus versiones no valían tanto como la palabra de un blanco.

Otras relaciones eran violentas, los amos golpeaban a las esclavas, las encerraban, las llevaban a las panaderías cuando éstas se negaban a sus requerimientos o tenían contacto con otros hombres. Los celos podían nublar la razón del propietario más apasionado. Así le sucedió a la mulata María del Rosario, cuando en 1790 su amo la arrastró de los cabellos por las calles de Lima mientras le propinaba patadas porque la encontró charlando con un vecino; tal fue el escándalo que varias personas intervinieron defendiendo a la esclava oponiéndose a que sea llevada a una panadería para ser azotada. El caso fue tan comentado que llegó a los tribunales. ${ }^{28}$

Pero no todas las relaciones se iniciaban por imposición del amo. Muchas esclavas usaban sus encantos para seducir al amo dentro de la casa, en las narices de la esposa y de esa manera mejoraban sus condiciones de vida: ropa, alimentos, propinas, permisos, etc. Una mulata, casi blanca, se fugó de la casa del amo, luego pidió ser vendida en menor cantidad y exigió que su amo le devuelva sus cosas. Al ver la lista, uno se asombra ante la descripción de ropa fina, sobre todo camisones de dormir, muebles y enseres. Más sorprendente aún es la reacción del propietario que aceptó la demanda de la esclava, dándonos motivos para sospechar la existencia de una relación sexual o afectiva entre ambos. ${ }^{29}$

¿Existieron sentimientos y relaciones de afecto entre amos y esclavas? Al parecer sí. Muchas partidas de bautizo, cartas de libertad graciosa y testamentos reflejan veladamente este asunto. Algunos hombres libres reconocieron a sus hijos esclavos, como Sebastián Gómez quien mandó a la esclava Juana Ramírez bautizar a la hija de ambos y le dio dinero para manumitirla. ${ }^{30}$ Otros otorgaron la libertad a la mujer y los hijos, como el marinero Juan de Mendoza quien en su testamento declara a su hijo natural Alonso y menciona a la madre Natalia de Cabo Verde, quienes recibieron un dinero para su manumisión. ${ }^{31}$ Otros preferían no especificar los vínculos otorgando poder a alguien para entregar dinero "para los fines ya explicados", "para las personas ya indicadas", "ya sabe lo que hará". Incluso hay casos donde la esclava, con hijos del amo, vive en la casa como dueña y señora. Así sucedió con la madre de María Arias. Ella fue criada en casa de

\footnotetext{
${ }^{28}$ Archivo Arzobispal de Lima, Causas de negros, legajo 33, 1782.

${ }^{29}$ Archivo Arzobispal de Lima, Causas de negros, legajo 32, 1750.

${ }^{30}$ Archivo Arzobispal de Lima, Amancebados, 1627.

${ }^{31}$ Archivo General de la Nación. Notarios, Cristóbal Rodríguez, protocolo 163, 1612.
} 
su padre Salvador Arias hasta que éste decidió casarse, liberando previamente a la esclava y a la hija. ${ }^{32}$

En estas historias sexuales también se involucraban clérigos. Muchos de ellos poseían esclavas, mantenían relaciones con ellas y al procrear hijos los criaban en la casa. Algunos liberaban a su familia, pero otros los vendían sin remordimiento. Estas relaciones podían darse de forma muy discreta, pero en otros casos el clérigo arrendaba una habitación para los encuentros furtivos, mientras que algunos pícaros ingresaban al domicilio de la amada, aunque ésta sea casada. Ese fue el caso de la esclava mulata Beatriz de San Joseph, quien vivía con su marido en una habitación aparte de sus amos. Un día el marido regresó de improviso y se tropezó en la entrada con un hombre semi desnudo, abochornado y con la sotana en la mano, al interpelar a Beatriz, ella fríamente negó la relación diciendo que el clérigo pasaba por ahí simplemente. ${ }^{33}$

En cambio, las relaciones entre amas y esclavos están rodeadas de un halo de silencio total, no quedan huellas en los documentos pues éstas se ocultaban con el mayor celo porque implicaba un deshonor para la mujer y la familia, pero si las relaciones eran descubiertas, ella podía apelar a un recurso: acusar al esclavo de violación. Después de eso la mujer se confinaba en el convento o su propia casa, muerta en vida para la sociedad, mientras el esclavo llevaba la peor parte pues era castrado y ajusticiado. ${ }^{34}$

Para el siglo XIX, las relaciones sexuales continuaron, algunas silenciosas y otras con escándalo público, gritos y golpes en los tribunales. Uno de los casos más sonados fue protagonizado por los esposos María Alvarado y don Cayetano Espinoza, y su esclava Vicenta. Todo empezó cuando doña María sospechó que su

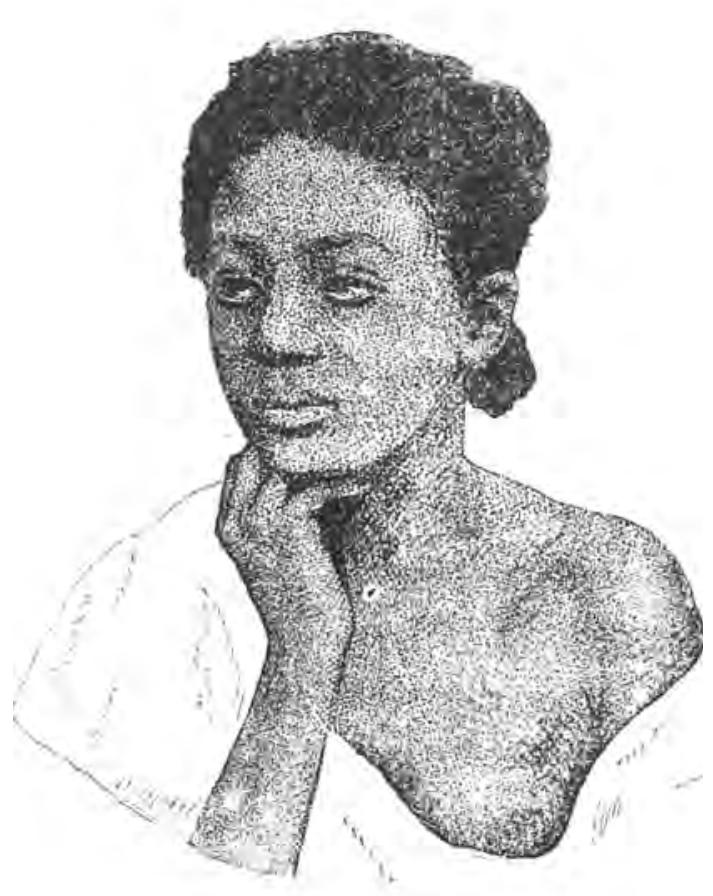

Mulata representada en el libro Perú y Bolivia de Charles Wiener.

esposo mantenía un romance con la esclava en su misma casa, así que decidió enviarla a casa de un amigo pero el esposo, al enterarse, sacó a Vicenta violentamente rompiendo puertas y ventanas. Hasta aquí parece que don Cayetano sólo estaba ejerciendo sus derechos como propietario pero luego doña María entabla un juicio contra la esclava acusándola de haberla amenazado de muerte. La respuesta inmediata de los familiares y amigos de Vicenta fue hacer un escándalo en la puerta de doña María.

Por eso, doña María pidió al tribunal vender la esclava fuera de Lima. No sólo eso, la acusó de mantener relaciones con su esposo: "la mencioi-

\footnotetext{
${ }^{32}$ Archivo General de la Nación, Real Audiencia, causas civiles, Legajo 87, Cuaderno 3231632.

${ }^{33}$ Citado por Lavalle, Bernand. Amor y opresión en los Andes coloniales. Lima: IFEA, IEP, URP, 1999, pág. 61-62.

${ }^{34}$ Muy pocos historiadores se han aventurado a tocar este tema, recién ahora hay una preocupación por ingresar a la vida intima de las personas. Ver los trabajos de Macera, Pablo (1977); Hünefeldt, Christine. Esclavitud, emociones y libertad. Lima: IEP, 1987; Mannarelli, María. Pecados públicos. La ilegitimidad en Lima, siglo XVII. Lima: Flora Tristán, 1994 y Arrelucea, Maribel (1999).
} 


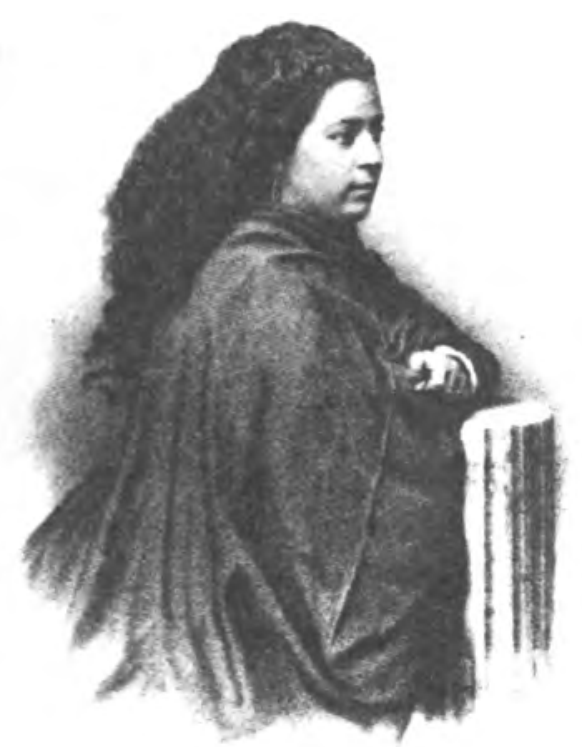

Grabado que representa una zamba limeña aparecido en Lima. Apuntes historiográficos descriptivos, estadísticos y de costumbres. Manuel Fuentes.

nada sierva, con la desenvoltura de que usa una mujer prostituida procuró proporcionar los medios de invitar a mi marido don Cayetano para que incurriese en la debilidad de tener acto ilícito con ella. La obscenidad con que se le presentaba, sus indecentes movimientos y otras maniobras con que le preparó el lazo obraron sobre mi marido el efecto de dejarse arrastrar por sus halagos, y de romper la fidelidad debida al matrimonio". En pocas palabras, Cayetano, como todo hombre, era muy débil mientras que la culpable era la esclava. Y termina así: "Usted sabe muy bien las arterías de que puede valerse una esclava teniendo en mira la ganancia de la libertad" (¿Quiso decir que el juez también tenía una aventura similar?).

En esos días apareció un artículo en El Mercurio Peruano denunciando el caso de Vicenta y tomando partido por ella. Afirma que se trató de un caso de seducción pero por parte del amo y que ninguna esclava puede librarse de ese tipo de seducción porque procede del temor.
Dos días después apareció una réplica defendiendo a don Cayetano insistiendo en la idea generalizada de ver a las esclavas como mujeres de naturaleza liviana. Una nueva réplica apareció tildando a don Cayetano de "niñito de escuela, seducido por su inocente esclava". Al fallecer abruptamente doña María, don Cayetano recién vendió a la esclava. ${ }^{35}$

\section{Los jornaleros}

El sistema basado en el jornal fue muy empleado desde el inicio de la época colonial, sobre todo en los centros urbanos. El sistema era sencillo: a veces el amo buscaba un trabajo para su esclavo, luego fijaba el jornal diario con el empleador y percibía una parte del monto; la otra era para el esclavo. En muchas ocasiones, el esclavo salía a la calle y buscaba un empleo eventual como cargador, vendedor, matador de reses, cocinero, panadero, etc. Al finalizar el día o la semana entregaba el monto fijado previamente por el amo.

Los jornaleros podían ser esclavos artesanos especializados en albañilería, pintura, sastrería, textiles, etc. En este caso, se cotizaban por encima de aquellos que no tenían una especialización laboral. Pero por lo general, los jornaleros no requerían ser diestros en un oficio porque en las ciudades grandes había una buena oferta de ocupaciones eventuales, como cargadores de bultos, aguadores, arrieros, vendedores de comida y dulces, cuidadores de ganado, peones para la cosecha o el berbecho en las chacras cercanas, etc.

Muchos jornaleros fueron exitosos a tal punto que mantenían a su propia familia, vivían en cuartos alquilados, compraban muebles, contraían deudas, eran testigos de bodas y hasta amortiguaban el precio de su cabeza o de la esposa e hijos hasta conseguir la libertad. Otros, por el contrario, no lograban juntar el dinero del jornal o no conseguían trabajo, por loque eran azotados

\footnotetext{
${ }^{35}$ Este interesante caso fue analizado por Aguirre: 1993: pág. 156-158.
} 
cuando eran encontrados, o sus amos los colocaban en las panaderías como castigo.

El sistema basado en el jornal significó una independencia para el esclavo y un alivio para el propietario quien ya no se preocupaba por los gastos del esclavo, y solo recibía su renta. Pero también existían desventajas: un jornalero podía evadirse, dejar de pagar sus jornales, enfermarse, incluso morir fuera del control del amo. Eran algunos riesgos que los propietarios de esclavos decidieron asumir con tal de obtener una renta.

Hacia mediados del siglo XIX, los jornaleros seguían trabajando bajo las mismas condiciones coloniales. Pasó a ser un sistema importantísimo pues muchos amos anteriormente ricos se arruinaron con las luchas por la independencia, y sus esclavos se convirtieron en la única renta. Según Manuel Atanasio Fuentes, el jornal era fijado a razón de un real diario por cada cien pesos del precio del esclavo. Por lo tanto, si un esclavo valía trescientos pesos, su jornal diario debía ser de tres reales. $^{36}$

\section{Los esclavos artesanos}

Si bien el trabajo esclavo está asociado con la agricultura y el servicio doméstico, también realizaban tareas especializadas. La demanda de mano de obra calificada era tan grande que varios maestros artesanos, desde el siglo XVI, compraban bozales y les enseñaban el oficio, después los vendían a precios más altos. Muchos propietarios de esclavos preferían colocarlos bajo la dirección de un maestro con el mismo fin, cobraban una renta; al mismo tiempo, el esclavo aprendía el oficio, incrementándose su valor.

Estos esclavos artesanos estaban en todas partes. En las haciendas, molinos y trapiches se necesitaba mano de obra calificada. Normalmente una hacienda cañera tenía un maestro azucarero, ayudantes, clarificadores, carpinteros, alfareros, herreros y carboneros. Otras viñas mantenían esclavos propios para fabricar botijas y odres. También había esclavos especializados en albañilería, canteros, adoberos, tejeros, ebanistas, etc.

En las ciudades, los artesanos esclavos eran muy apreciados. Sobre todo en actividades como la albañilería. Muchos esclavos especializados trabajaron en la construcción de diversas obras como las cañerías de barro en Lima; igualmente en los puentes de piedra, conventos, casonas, iglesias, hospitales, callejones, etc. Estas actividades también fueron cubiertas por libertos como Francisco de Gamarra, albañil negro muy conocido en Lima durante el siglo XVII; Juan de Mora, un mulato arquitecto quien construyó un portal para una capilla en la iglesia de la Merced, en Lima; o Fernando Joseph, un mulato libre, ebanista y mueblero quien en 1639 trabajó en la construcción de las sillas del coro de la catedral de Lima. ${ }^{37}$

La mayoría de veces, el maestro español compraba o contrataba a jornal un grupo de esclavos, como Juan del Corral, maestro albañil quien construyó el puente de piedra de Lima en el siglo XVII. Para esta obra organizó una empresa constructora comprando esclavos y arrendando otros cuyos precios oscilaban entre 600 y 700 pesos. Gracias a su testamento, publicado por Antonio San Cristóbal, sabemos los nombres de algunos de estos esclavos, como Pedro Bio, Pedro y Antón Biafra, quienes trabajaron a jornal. Pero también tenía esclavos propios: los carpinteros Antón Bran y su mujer Catalina Bran; Juan Bran, los aserradores Juan Falupo y su mujer María; Nicolás Bran, Francisco Bañol, Francisco Biafra, Antón Congo, Antón Quipuga, Antón Padilla Angola, Juan Latín, Alejandro Angola y Domingo Luis. También el herrero Juan Angola, una mujer llamada Ana Bran y un niño de ocho o

\footnotetext{
${ }^{36}$ Fuentes, Manuel. Lima, apuntes historiográficos, descriptivos, estadísticos y de costumbres. Lima,1984.

${ }^{37}$ Bowser, Frederick, ibid, pag. 177. Otros estudios importantes sobre artesanos: Hartterre, Emilio y Márquez Abanto. "El artesano negro en la arquitectura virreinal limeña". Revista del Archivo Nacional, XXVI, 1963 y Quiroz, Francisco. Gremios, razas y libertad de industria. Lima colonial. Lima: UNMSM, 1995.
} 
nueve años a quien seguramente se estaba adiestrando. $^{38}$

Otro oficio importante fue el relacionado con los metales. La herrería fue fundamental durante la conquista y las guerras civiles. Allí los esclavos participaron como herreros, forjaban espadas, lanzas y mantenían las fraguas abastecidas de carbón. También acompañaron a exploradores y conquistadores hacia las zonas periféricas. Un esclavo herrero formó parte de la expedición de Álvaro de Mendaña al Sur en 1567.

En cambio, pocos esclavos fueron plateros, doradores o batidores de oro. Estos oficios eran considerados de mucho prestigio por los españoles y los reservaron para sí. Otras actividades también empleaban esclavos, como por ejemplo en la albañilería, fabricación de ladrillos y tejas, azulejos, vidrio, curtido y manufactura del cuero, elaboración de velas, preparación de chocolates, etc. Para 1574 se menciona a un negro liberto como fabricante de sillas de montar trabajando en Lima con tienda propia. El mercurio proveniente de las minas de Huancavelica se transportaba en bolsas de cuero fabricadas por esclavos.

La elaboración de telas y prendas de vestir fue otra actividad que contó con la mano de obra esclava. Había esclavos zapateros, sastres, remendones, bordadores, encajeros, calceteros, sombrereros, etc. Pero se dio una fuerte oposición de los maestros españoles e indios, por eso algunos miembros excluyeron a los esclavos y otras castas de sus gremios.

La cantidad de esclavos artesanos fue creciendo con el tiempo. Podían empezar como aprendices y después de un examen tomado por un maestro del gremio, podían ser oficiales pero no llegaban a maestros. Esta prohibición mantenía a los esclavos subordinados a un maestro y evitaba la competencia.

Estos esclavos artesanos gozaban de mejores condiciones de vida y su precio se elevó. Asimismo, percibían mayores salarios que otros esclavos e incluso más que una persona libre; podían vivir en casa del maestro, en el taller o alquilar su propio cuarto; tenían su propia familia, compraban cosas, y algunos lograban automanumitirse. También se preocupaban por el futuro de sus familiares, algunos automanumitían a la esposa, otros a sus hijos pequeños, y celebraban contratos con los maestros artesanos para que sus hijos aprendan el oficio.

\section{Los oficios menores}

Los esclavos también se desempeñaban en los llamados oficios menores, es decir, ocupaciones consideradas inferiores, pues eran despreciados por la mayoría de la población. Eran negros, zambos y mulatos los que trabajaban en el matadero de las ciudades donde remataban y destazaban las reses separando los desperdicios de las piezas destinadas a la venta. En los puertos, los esclavos se encargaban de cortar, salar y curar la carne consumida en las travesías.

Igualmente eran empleados en la preparación y venta del pan y dulces. Las panaderías eran comparadas con el infierno porque el ritmo de trabajo era agobiante, los hornos elevaban la temperatura, la humedad era permanente, la comida escasa, no había camas, dormitorios ni botiquín, pero sí cadenas y látigos como parte de los enseres. Pocos trabajaban voluntariamente en las panaderías, por lo general los propietarios llevaban hasta allí a sus esclavos más díscolos, cimarrones, ladrones, etc., quienes eran castigados con azotes o encadenados para que trabajen varias temporadas. Como era muy difícil vender esclavos con esos antecedentes, los propietarios los llevaban a las panaderías para venderlos. Era la solución ideal porque de alguna manera encontraban comprador, percibían el jornal del esclavo y además evitaban la fuga. La Real Audiencia hacía lo mismo. Cuando se capturaban cimarrones, ladrones o palenqueros, no los llevaban a la cárcel como correspondía, sino a

\footnotetext{
${ }^{38}$ San Cristóbal, Antonio. "Negros en la construcción del puente de piedra. Anexo documental". Historia y cultura, 24, 2001.
} 
una panadería. Así, evitaban la fuga y ganaban el jornal del esclavo. ${ }^{39}$

Otros esclavos se desempeñaban como cargadores de bultos, angarilleros (cotidianamente los miembros de este grupo se paraban en una esquina de la plaza mayor para cargar objetos delicados empleando unas literas llamadas angarillas), carretoneros, limpiadores de acequias, matadores de perros, curtidores, aguadores (tan numerosos que poseían su propio gremio en Lima), etc.

La venta ambulatoria caracterizaba la vida cotidiana de las ciudades, especialmente de Lima. Esta actividad era realizada por mujeres negras, zambas, mulatas e indias que ofrecían dulces (roscas, leche agria, crema batida, quesos, aloja, buñuelos, bizcochos, etc.) bebidas (chicha de jora, de maní o habas), comidas (picantes, guisos, sopas), flores en ramos o las llamadas mixturas, velas, estampas, loterías, pañuelos, ropa de todo tipo, nueva y usada, herramientas y utensilios, etc. En las plazas principales de las ciudades coloniales era usual encontrar a estas mujeres vendiendo sus productos en puestos de madera, también caminando por la calle cargando sus mercancías en canastas o sobre tablas en la cabeza dando un toque pintoresco.

Por otro lado, muchos negros y mulatos, hombres y mujeres, fueron dueños o arrendatarios de pulperías, tambos y chinganas, lugares donde se podía comprar artículos de consumo diario y tomar vino en vaso, jugar a los dados y naipes, conversar, comer, etc. Pero también constituyeron lugares de encuentro y peleas entre personas de diferente casta y condición. Allí se reunían libres y cautivos, blancos, negros e indios, "decentes" y proscritos, cimarrones y ladrones conocidos, desertores y prostitutas, hombres y mujeres. Estos centros constituían

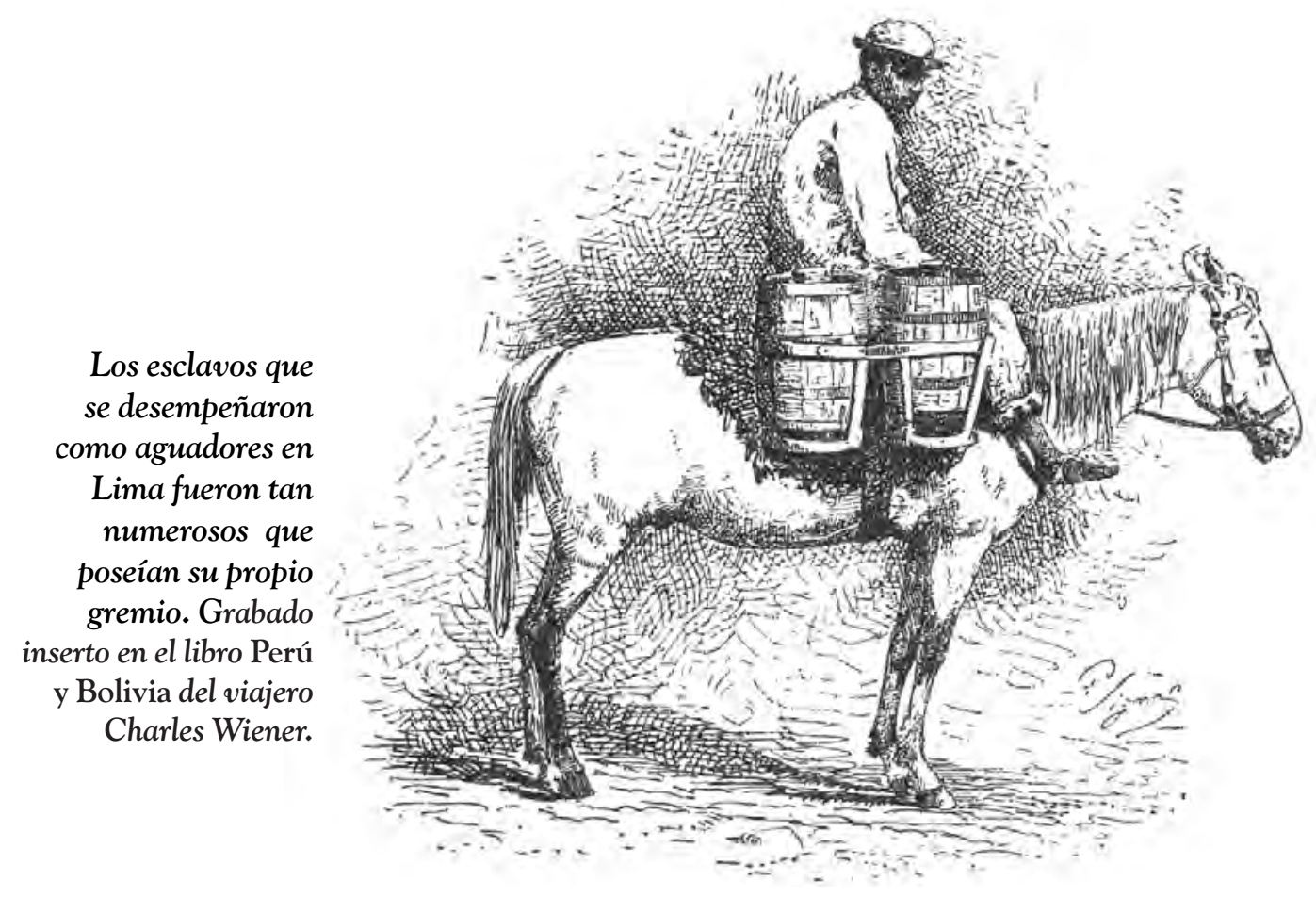

\footnotetext{
${ }^{39}$ Arrelucea, Maribel. "Conducta y control. Estudio de las panaderías limeñas, siglo XVIII". Revista del Archivo General de la Nación, 13, 1996.
} 
espacios abiertos usados también por la gente marginal para planear robos, intercambiar información, etc.

Los esclavos también eran empleados en el transporte que conectaba las ciudades del interior del virreinato. Para transportar plata, oro, mercurio, mercadería importada, esclavos y otros productos, usaban carros jalados por mulas o bueyes. Estos viajes eran peligrosos por las condiciones de los caminos y puentes. Muchas veces cuando estaban frente a un puente endeble o un río enmarañado, era preferible pasar la mercadería en hombros de los indios, libertos y esclavos.

También, tanto los buques mercantes de la Corona como los privados que surcaban el océano Pacífico, tenían marineros esclavos y libertos. Según Bowser, pocos lograron ascender en este oficio, citando el caso de un capitán mulato que comandaba un buque llamado San Nicolás. ${ }^{40}$ Es de resaltar que para la elite todos estos oficios: marineros, muleteros o arrieros, ambulantes, matarifes, etc., eran inferiores porque no sólo requería usar la fuerza física, también muchos de ellos se ejercían al aire libre, en el espacio público, y a veces se tornaban violentos, en el límite entre lo legal y lo ilegal.

\section{Matrimonio, familia y religiosidad}

\section{Matrimonio y familia de esclavos}

La iglesia se encargó de administrar el sacramento del matrimonio. Durante el siglo XVI, en el marco del Concilio de Trento y ante el avance de los protestantes, la iglesia debió redefinir los principios matrimoniales. Así, con la doctrina del libre albedrío opuesta a la predeterminación, la iglesia defendió el consentimiento libre y voluntario para el matrimonio. Ya en el siglo XVII, se pensaba que el amor era un ejercicio libre e individual, así que para vivirlo se debía establecer el vínculo matrimonial.
El matrimonio era el único espacio legítimo para la reproducción y las relaciones sexuales. Por eso la iglesia defendió los matrimonios de esclavos con la intención, también, de reducir el amancebamiento y los hijos ilegítimos. Se estableció como obligación de los amos casar a sus esclavos y darles permiso para dormir juntos. En la práctica esto dependía de la voluntad de los amos, quienes señalaban los días destinados a la pareja, generalmente los fines de semana o un día a la semana.

La defensa de la iglesia se nota en los dos Concilios Limenses reunidos primero entre 1567 y 1568 y luego de 1582 a 1583. En ambos se declaró que los amos no debían oponerse al matrimonio de esclavos ni separar a los casados, esto implicaba no vender a un esclavo casado fuera de su lugar de residencia.

En el caso de esclavos de diferentes amos, la iglesia sugería a uno de los amos comprar al esclavo, cosa que muy pocas veces se cumplía. Por lo general, los propietarios se ponían de acuerdo cuántos días y cuáles se permitirían a la pareja, aunque no todos los amos eran comprensivos. Existen numerosos juicios de esclavos quejándose porque el amo de la esposa se niega a dejarla a "hacer vida maridable", es decir dormir con el esposo. Por otro lado, también se permitía el matrimonio mixto e interétnico, es decir esclavos con personas libres de otras castas. Bastaba el consentimiento del amo para establecer el vínculo matrimonial.

Esta preocupación de la iglesia abrió un frente de defensa para los esclavos pues muchos acudían al Tribunal Eclesiástico para evitar la expatriación o la venta fuera del lugar de residencia, aduciendo la ruptura del sacramento matrimonial. Y la iglesia, después de asegurarse que el esclavo no era un delincuente, amonestaba al amo.

Resulta importante observar que la mayor parte de estas peticiones para evitar la expatria.

\footnotetext{
${ }^{40}$ Bowser, 1977: pág. 139.
} 

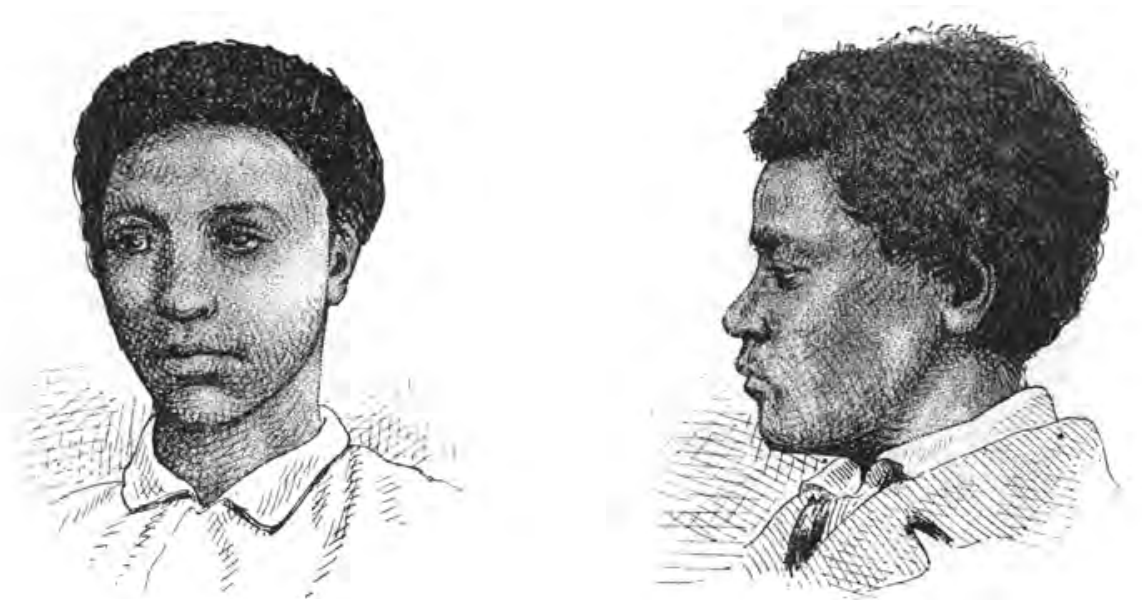

Zambo y mulato, grabados insertos en el libro Perú y Bolivia del viajero Charles Wiener.

ción era presentada por mujeres, sobre todo esposas y en menor proporción madres de esclavos. Una menor cantidad fue presentada por hombres, todos esposos de esclavas. Algunas peticiones eran airadas, otras en cambio, apelaron a los sentimientos de los jueces escribiendo conmovedoras cartas. Así hizo Rita, una esclava limeña con cuatro meses de casada. Sin embargo, su esposo, también esclavo, vivía en Chancay. Ella, a través de un abogado, suplicó que lo vendan en Lima porque "en el día me hallo en un todo trastornada de la cabeza con tan súbita separación y por esa razón no tengo sosiego para desempeñarme en ninguna de mis funciones de mi esclavitud por lo que también recomiendo a Vuestra Señoría el asunto pues me hallo expuesta a perder el juicio". Otro esclavo pedía lo mismo, que vendan a su esposa en la ciudad de Lima porque la extrañaba "tan tiernamente como dada por la Santa Iglesia". ${ }^{41}$

Muchos novios rompían por la oposición de los padres, quienes presentaban como principal excusa la diferencia racial entre los contrayentes, incluso más que las económicas. Más de un novio enamorado fue tildado de zambo, mulato, hijo de negro, zambaigo, etc. Igual sucedió con las mujeres. Tener un poco de sangre negra no solo implicaba ser inferior, sino también otorgaba dudas sobre la virtud, pues casi siempre el insulto de negra o mulata venía acompañado de puta.

Si desde un principio la iglesia controló la sexualidad y el matrimonio, en el siglo XVIII ese control aumentó. Esto coincidió con el poder creciente del Estado borbónico. Carlos III expidió la Real Pragmática en 1776 regulando el matrimonio entre iguales, personas de similar casta y condición. Estas nuevas medidas otorgaron mayor poder a los padres para evitar matrimonios aduciendo diferencias entre los contrayentes. De esta manera, muchas uniones se rompían ante el mayor poder otorgado a los padres pero también ante la oficialización del criterio étnico de inferioridad en el momento de la elección matrimonial que seguirían vigentes en el siglo XIX.

¿Existió una familia esclava? Algunos sostienen que no porque el esclavo es visto como un ser desarraigado que podía ser vendido en cualquier momento; pero la investigación revela que sí lograron construir sus propias unidades familiares con ciertas peculiaridades y limitaciones.

El esclavo estaba sujeto al propietario, debía seguirle a todas partes, podía ser vendido a un

\footnotetext{
${ }^{41}$ Archivo Arzobispal de Lima, Causas de negros, Legajo 33, 1790.
} 
económicos y su capacidad adquisitiva era limitada. Por otro lado, la esclava también afrontaba estas limitaciones además de la transmisión de la esclavitud a sus hijos: ellos heredaban la condición de la madre sin importar quién era el progenitor, la esclava criaba a sus hijos, les enseñaba a desempeñarse en ciertas actividades domésticas, trabajaban con ella y por lo general eran vendidos con la madre cuando eran muy pequeños. Cuando los hijos estaban más grandes podían ser vendidos y separados de la madre, pero cuando se analizan las cartas de compra y venta se observa que en su mayoría los hijos eran vendidos dentro del mismo espacio de residencia: una hacienda cercana o en la misma ciudad.

Se puede afirmar entonces que la familia esclava era básicamente matrifocal ${ }^{42}$, pues los hijos estaban más ligados a la madre pero también hay familias donde el padre esclavo asume el rol protector, paternal y dominante. Las peculiaridades de la esclavitud, implantadas desde la Colonia, otorgaron al esclavo una familia con lazos débiles por estar subordinada al poder del amo pero al mismo tiempo no destruía los lazos sanguíneos y afectivos. Al contrario de lo que usualmente se cree, existieron padres y madres de familia preocupados por los problemas cotidianos que afrontaban al criar a sus hijos, tan igual como las personas libres, solo que con la carga de la esclavitud.

Una forma de abordar mejor este problema es atisbando en las casas. Se cree que todos los esclavos estaban privados de sus propios espacios porque vivían con sus amos pero no es tan cierto. Existe un Padrón del barrio de Santa Ana, en Lima, elaborado en $1771^{43}$, donde se revela que casi todos los esclavos del barrio formaban familias nucleares, es decir, padres e hijos. No vivían en la casa de sus respectivos propietarios, ellos alquilaban sus cuartos, compraban muebles, se preocupaban por problemas cotidianos tales como cubrir las necesidades de comida, ropa, calzado, medicina de los hijos. Un dato importante a tomar en cuenta es que se trata de esclavos jornaleros y artesanos, modalidades de trabajo que otorgaba mayores márgenes de independencia al esclavo. Entonces, observamos que no todos los esclavos estaban sin familia.

En algunas haciendas, los esclavos eran encerrados en galpones, especie de habitación rectangular, uno para hombres y otro para mujeres, en este último se incluían los niños. Esto les permitía formar lazos familiares muy fuertes con la madre, porque ella cuidaba de los hijos, se los llevaba a trabajar a la chacra o a la cocina de la casa, los alimentaba y los tenía hasta que eran vendidos o llevados a la ciudad. Otros propietarios entregaban una parcela a cada pareja y allí construían su choza obteniendo así una vida familiar más estable.

Igualmente, se piensa que los esclavos eran seres desarraigados, sin familiares. Sin embargo, encontramos esclavos urbanos y rurales litigando acompañados de sus parientes más próximos, algunos se fugaban e iban directo a la casa de los padres, hermanos, tíos o padrinos. Al revisar los juicios a los cimarrones o bandoleros, encontramos a sus parientes, generalmente las mujeres de la familia, litigando en su defensa. Igualmente, cuando se trata de escoger padrinos o testigos de boda también se tomaba en cuenta los lazos de parentesco. Cuando revisamos las cartas de libertad, muchos de ellos son del padre de familia comprando la libertad de la esposa o algún hijo.

Por otro lado, no todos los matrimonios eran hasta la muerte, las parejas afrontaban diferentes

\footnotetext{
${ }^{42}$ Sin embargo, María Emma Mannarelli opina que la esclavitud inhibía la posibilidad de formar un hogar. Pero la esclavitud colonial y decimonónica no destruyó los lazos de parentesco ni los amicales. Mannarelli, María. Pecados públicos, la ilegitimidad en Lima, siglo XVII. Lima: Flora Tristán ediciones, 1996.

${ }^{43}$ Este Padrón fue estudiado por Quiroz, Francisco, "Análisis de un padrón correspondiente a un barrio de Lima (1771)". Actas del Congreso Nacional de Investigaciones Históricas, Humberto Rodríguez Pastor (Editor), Lima: CONCYTEC, 1990.
} 
problemas que se agudizaban cuando uno de los cónyuges era esclavo. Los juicios de nulidad de matrimonios revelan un problema presente en muchos matrimonios mixtos: la inferioridad que se atribuía al esclavo también era trasladada al matrimonio, el cónyuge esclavo podía ser más débil y recibir insultos, golpes y maltratos porque el libre se sentía superior. Un esclavo siempre era inferior, aún ante los ojos de su cónyuge.

Por otro lado, la supuesta superioridad del varón también era interiorizada por los esclavos y libertos quienes agudizaban los problemas conyugales al ejercer el dominio sobre sus esposas, algunas veces con violencia y abusos, aún cuando ellas eran libres. Ese fue el caso de Lorenza Criolla, una morena libre limeña quien denunció a su marido Antonio Bermúdez, moreno esclavo, por adulterio. Lorenza se quejó que su marido andaba con varias mujeres desde los inicios del matrimonio, tenía una manceba (amante) llamada Felipa, una negra esclava embarazada a quien la mantenía abiertamente ante todos mientras que a ella no le daba nada. ${ }^{44}$

Un matrimonio desigual que luego lograba la relación horizontal, a veces no podía mantenerse como el caso de María de Aspitia y Francisco Portierra. Poco después del enlace matrimonial, María pudo automanumitirse y acusó a Francisco de adulterio pidiendo la nulidad del matrimonio, pero él acudió a los tribunales aduciendo que ella era la adúltera y que había cambiado desde su liberación, acusando a María de manejarse libremente (ya no era esclava sujeta al amo ni quería permanecer subordinada al marido). ${ }^{45}$

¿Cómo, a pesar de estos factores disolventes, muchos esclavos mantuvieron sus lazos de parentesco? Creo que la respuesta está en el sistema mismo de la esclavitud colonial: como no era de primera importancia, desarrolló algunas peculiaridades que terminaron otorgando al esclavo ciertas libertades como el sistema a jornal y las chacras. Además, el factor geográfico también fue importante, los esclavos permanecían en una zona próxima: un valle, la ciudad, un barrio, etc., donde era posible seguir manteniendo lazos de parentesco y protección aún a pesar de la venta a otro propietario.

\section{La religiosidad: entre la conversión y la hechi- cería}

Según la legislación, los esclavos traídos a América debían ser bautizados en la fe católica para que al tomar contacto con los indígenas no se expandan las herejías. Perolos asentistas, preocupados en sus ganancias, casi no se daban tiempo para bautizar a sus mercancías humanas, otros apenas contrataban un cura para que les arroje el agua bendita a todos juntos, a manera de baño colectivo. A medida que pasaron los años, se hizo evidente la necesidad de catolizar al bozal, occidentalizarlo antes de servir a un amo. La primera vez que la Corona planteó este asunto fue en 1569, cuando pidió informes al Arzobispado porque todavía algunos esclavos practicaban costumbres paganas.

La iglesia, por su parte, enviaba curas para dar sermones a los esclavos de haciendas todos los primeros domingos de cada mes, incluso los jesuitas tuvieron la iniciativa de escribir un diccionario y gramática de "la lengua de Angola" junto con una guía para confesores preparados en ese idioma. Muchos predicadores llegaron a ser muy conocidos. Bowser cita al padre López que lograba atraer a San Pablo hasta 200 esclavos todos los domingos para una clase de religión. El padre Piñas, conocido por ser el predicador favorito del virrey Toledo, solía ir a la plaza mayor de Lima, se trepaba en un banco y sermoneaba a los esclavos que trabajaban allí. Otro padre famoso fue el padre Portillo, llamado también "la trompeta de Dios" por su voz resonante, lograba conmover a sus oyentes hasta hacerlos llorar, mientras que el padre Gonzáles,

\footnotetext{
${ }^{44}$ Archivo Arzobispal de Lima, Divorcios, Legajo 15, 1634.

${ }^{45}$ Archivo Arzobispal de Lima, Divorcios, Legajo 33, 1656.
} 
era tan estricto que muchos amos mencionaban su nombre para tranquilizar a sus esclavos. ${ }^{46}$

Los jesuitas también innovaron la catequesis pues sus predicadores estaban en todos lados: los mercados, las plazas, los funerales, los bautizos y los matrimonios. También en las cárceles, las panaderías, los hospitales y hasta en la Casa de la Moneda. Incursionaban en las casas, los obrajes y las haciendas. Su celo era tan grande que invadían hasta los espacios privados, siempre emplazando a los indolentes amos a bautizar a sus esclavos, aunque parece que estos no tenían mayor interés porque revisando las cartas de compra y venta hay numerosos y frecuentes casos de esclavos sin bautizar, incluso a fines del siglo XVIII.

Sin embargo, a pesar del esfuerzo de los predicadores, los esclavos, bozales y criollos, al igual que españoles e indígenas crearon una cultura alterna, caracterizada por elementos nativos, supersticiones y herejías. Muchos esclavos, tanto en las haciendas como en las ciudades, se dedicaban a curar enfermedades corporales y espirituales, además de preparar filtros de amor, amarres amorosos, eliminar a las personas odiadas envenenándolos, etc. La iglesia condenaba estas prácticas consideradas como supersticiones y el Santo Tribunal de la Inquisición se encargó de perseguirlos y castigarlos.

Ricardo Palma logró anotar diligentemente algunos nombres de esclavos acusados por la Inquisición: María Teresa de Malavia, mulata, soltera, de 28 años, natural del Callao; Sabina Rosalía de la Vega, mulata, 40 años, casada, oriunda de Camaná; Bernabé Morillo, negro del Callao, cocinero, soltero de 30 años; Manuel de Jesús, congo, 60 años, viudo, esclavo de la hacienda San Juan de los jesuitas. En estas acusaciones afloran algunas prácticas como pasar el cuy o conejo, masticar hojas de coca, frotar el cuerpo con coca, preparar filtros de hierbas y flores para baños, etc. Otros empleaban la palma bendita, el hilo respondón (un imán atado al hilo "respondía" las preguntas del consultante), las clavijas (clavaban agujas a un muñeco de cera que representaba a la persona a la que se deseaba hacer daño), la mano de brujo (la mano seca de un ahorcado), agujetas (una aguja empleada anteriormente para coser mortajas era clavada en la ropa de un hombre para volverlo impotente) $)^{47}$.

Las personas acudían ante estos supuestos brujos para conseguir buena salud, dinero, suerte, el amor esquivo, etc. Pero también iban para dañar a otras personas, rivales de amores, vecinos envidiosos, parientes incómodos, etc. Por otro lado, los clientes eran de todos los grupos sociales y de todos los colores, blancos y negros, libres y libertos, encumbrados y humildes.

Es interesante remarcar que muchos esclavos adoptaron las creencias andinas, usando hojas de coca para la adivinación y la curación con cuy, efectuándose un sincretismo singular. Ese fue el caso de un cimarrón llamado Francisco (a) El Amantísimo. Decidió vivir en Chilca, en una zona indígena y cerca de su amo y amigos. Su principal actividad fue la curandería, auscultaba y diagnosticaba a los indígenas además de recomendarles escuchar misa. Al analizar sus métodos curativos observamos el uso de hojas de coca y el cuy para limpiar el cuerpo, aprendidos de una india. También usaba cintas para limpiar, oraciones como el Padre Nuestro, toques con un crucifijo de hierro y gestos que seguramente impresionaban a sus pacientes. ${ }^{48}$

Ricardo Palma publicó extractos de un juicio seguido contra Miguel Cosío o Galeano. Este era esclavo de una hacienda de Chancay que se hacía pasar por brujo fingiendo pacto con el diablo, decía poseer poderes sobrenaturales,

\footnotetext{
${ }^{46}$ Bowser, Frederick, ibid. pág. 305.

${ }^{47}$ Palma, Ricardo. Anales de la Inquisición de Lima. Lima: Congreso de la República, edición facsimilar, 1997.

${ }^{48}$ Arrelucea, Maribel. "De bandoleros y curanderos. Opciones del cimarronaje en la costa central". Revista del Archivo General de la Nación, 16, 1998.
} 
especialmente de sanación. Su última paciente, la esclava María Antonia, viajó desde Lima a Chancay porque varios amigos esclavos le recomendaron este brujo; ella sufría de hematomas e hinchazones en sus piernas, Galeano la curó abriendo y drenando las heridas. ${ }^{49}$

\section{Procesiones}

Las procesiones religiosas eran muy populares en la Colonia y la República decimonónica, toda la población participaba con entusiasmo y reverencia, incluidos los esclavos. Muchos viajeros y pintores han dejado sus impresiones como Tadeo Haenke, un viajero francés que visitó Lima en el siglo XVIII, describió la procesión del Corpus Cristi en éstos términos: desfilaban cuadrillas en orden riguroso, primero las comunidades religiosas, luego las instituciones políticas como el Cabildo, la Audiencia, los Tribunales, también los Regimientos de la ciudad y después las cofradías empezando las de la aristocracia, seguidas por las comparsas de indígenas y al final las comparsas de negros, diferenciándose los criollos de los bozales.

Cada grupo avanzaba encarnando la concepción que se tenía sobre cada casta, los blancos ordenados, bien vestidos, enjoyados; los indios con sus trajes típicos y plumas. Al final los bozales desfilaban medio desnudos, disfrazados de salvajes, con plumas y palos, bailando, gesticulando. Otros esclavos se disfrazaban de moros, gigantes y diablos, personajes negativos en el imaginario colonial. ${ }^{50}$

\section{Cofradías}

Las cofradías fueron instituciones sumamente importantes destinadas al culto de un santo patrón y dedicadas a la protección y ayuda mutua de sus miembros o cofrades quienes obtenían préstamos para diferentes objetivos: automanumitir un miembro, sufragar un entierro, asistir a una viuda o los huérfanos de un cofrade, etc.

Existían cofradías de negros bajo la advocación de Nuestra Señora de los Reyes, Santa María la Antigua, Nuestra Señora de la Victoria, San Bautista, San Antón, Nuestra Señora de Guadalupe, Nuestra Señora del Agua Santa y la Virgen del Carmen, la más popular de todas. Hacia 1650 se distinguían cofradías de negros criollos y bozales. Mucho después los criollos se separaron de los mulatos, distinguiéndose como pardos. También se agrupaban de acuerdo a la casta. Raúl Adanaqué (2001) ubicó cofradías de los negros Congo, Mina, Chala, Mozambique, entre otros.

Todas las cofradías estaban dedicadas al cuidado del altar del santo patrón en alguna iglesia pero las reuniones de los cofrades se hacían fuera del recinto religioso. Según William Bennet Stevenson, tenían cuartos alquilados en los suburbios de San Lázaro donde se reunían los domingos por la tarde, pero también existieron en el centro mismo de la ciudad como lo ha demostrado Adanaqué. El mismo Stevenson describe esos cuartos decorados con pinturas de escenas tribales, allí reconocían a sus reyes y reinas, recordaban sus costumbres y narraban las acciones míticas de sus dioses. También cita el caso de una vieja esclava reconocida como reina de los mandingas, que era transportada en un atrio de plata obsequiado por su amo. ${ }^{51}$

La cofradía más célebre es la del Señor de los Milagros, proveniente de los esclavos negros limeños, concretamente de Pachacamilla. La tradición cuenta que fue un esclavo angola quien pintó la imagen de Cristo crucificado sobre un muro que inexplicablemente permaneció en pie a pesar de un terremoto que destruyó edifido

\footnotetext{
${ }^{49}$ Palma, ibid, pág. 133-134. Obsérvese como la esclava pudo desplazarse de Lima a Chancay con el permiso de su amo sin problemas.

${ }^{50}$ Acosta, Rosa María. Una aproximación al estudio de la fiesta colonial en el Perú. Tesis, Lima: PUCP, 1979.

${ }^{51}$ Stevenson, William Bennet. "Memorias sobre las campañas de San Martín y Cochrane en el Perú". Colección Documental para la Independencia del Perú, Viajeros, vol. 3. Lima, Comisión del Sesquicentenario, 1971.
} 
cios y templos. La devoción aumentó entre la población negra y la procesión de la imagen congregaba principalmente a este grupo. Durante el siglo XIX la procesión organizada por esta cofradía continuó siendo patrimonio de los negros limeños quienes, según el testimonio de Pradier-Foderé, adoptaban actitudes agresivas ante la intrusión de alguna persona diferente: "En Lima no hay un negro, un zambo, un cholo que no pertenezca a una cofradía...cada color celoso de sus rivales". ${ }^{52}$ Eudocio Carrera fue más descriptivo: "Por doquier veíanse por igual, mujeres, morenas graciosas en buen número, vestidas de morado, con cirios encendidos y cubiertas las cabezas con mantos, velos y mantillas". ${ }^{3}$

\section{Aportes culturales}

El esclavo africano trajo consigo su propia cultura y supo adquirir otros rasgos culturales en su contacto con españoles, moros y portugueses: costumbres, instrumentos musicales, canciones, bailes, comidas, etc., que constituyen ingredientes fundamentales en la configuración de la cultura peruana actual.

\section{Música y danza}

Fernando Romero encontró una familiaridad entre el africano y algunos instrumentos musicales como el cajón, las quijadas, las maracas y las tejoletas; también el ganzá, el güiro, el tamboril, el checo y el juego de repicador y llamador, entre otros. Con estos instrumentos elaboraban su música alegre y festiva: la saña, la resbalosa, el zapateo, el alcatraz, el ingá, la conga, el festejo, etc. donde lo característico era, y es hasta hoy, el movimiento sensualdel cuerpo.

\section{Poesía}

Por otro lado, apareció un género de poesía popular cantado: las décimas, traída por los españoles y cultivada por ellos y los esclavos. Con el tiempo, se circunscribió a algunos lugares como Zaña, Chincha, Ica, Cañete y en algunos barrios de Lima. A pesar de un origen mestizo, las décimas se identificaron con los esclavos, y posteriormente con la población negra.

Según Octavio Santa Cruz ${ }^{54}$, la décima floreció durante la Colonia en diferentes estilos locales, desde décimas sueltas hasta décimas reunidas a partir de la coincidencia con un verso, generalmente el décimo, y en modalidades como el punto fijo, el pie forzado, y otras. Estas décimas se caracterizan por la improvisación y la música de una guitarra como acompañamiento. Las modalidades más conocidas son:

En la costa norte, las Cumananas. Según Marta Hildebrandt, es la copla de cuatro versos octosílabos. El primer verso y el tercero son libres, el segundo y el cuarto pueden ser de rima o consonante. La cumanana se canta, muchas veces improvisada, con acompañamiento de guitarra. En la costa sur, los huanchihualitos. Se le llama así a un contrapunteo generalmente pícaro que anima las fiestas de yunza o cortamonte. En esta modalidad, Santa Cruz encuentra elementos mestizos. En la costa central, el Amorfino. Era un canto de contrapunto, jactancioso y retador.

Uno de los más entusiastas difusores de las décimas fue Nicomedes Santa Cruz quien también fue autor de muchas célebres como la siguiente:

\section{Voy a cantar un palmero de esos que llegan al alma cuando saque mi pañuelo: "Palmero sube a la palma"}

\section{Alimentación y comidas}

Dependiendo del amo, los esclavos se alimentaban con verduras: maíz, papa, camote, zapallo, también con los desechos de las reses

\footnotetext{
${ }^{52}$ Pradier-Fodere. Lima et ses environs. París: Pedone, 1897, pág. 191.

${ }^{53}$ Carrera, Eudocio. La Lima criolla del 900. Lima: 1954, pág 247.

${ }^{54}$ Santa Cruz, Octavio. "De la métrica de Espinel al temple maulío". Historia y cultura, 24, 2001.
} 
(mondongos, lengua, riñones, hígados); en algunas ocasiones recibían pan, harinas, menestras, pescado o res. Además, en las haciendas y en las ciudades, era obligatorio dar a los esclavos dotaciones de tabaco y en fiestas, aguardiente y guarapo.

En 1616, una hacienda de Mala productora de trigo y alfalfa, con once esclavos invertía "generosamente" en la alimentación de sus trabajadores pues cada cinco o seis semanas mataban un ternero, repartían la carne, acompañada de frejoles, maíz y pan. Los viernes y sábados repartían pescado, huevos, plátanos, miel y tabaco. Los esclavos complementaban su dieta con los productos de sus pequeñas huertas y la crianza de animales. ${ }^{55}$

Gracias a su inventiva y sazón, además del contacto con la cocina indígena y española (influenciada por la árabe), surgieron platillos considerados exquisitos y representativos de nuestra mesa. Los ingredientes básicos fueron aquellos que los amos les entregaban: harinas y tubérculos (aprendieron a prepararlos como los indígenas), vísceras, huevos y especias (canela, clavo, anís, propio de la cocina árabe).

La lista es larga y apetitosa: los anticuchos, el choncholí, la pancita, la chanfainita, el cau cau, los tamales, la sangrecita, el tacu tacu o calentado, los adobados, además del cebiche, también los dulces como el zango, el champúz, los buñuelos, que horadados en el centro fueron convertidos en los dulces picarones, el alfajor o alajú, las cocadas, la chapana, las humitas, la mazamorra morada, el turrón de doña Pepa, etc. Todos tienen riquísimos orígenes negros.

\section{Afronegrerismos}

Los esclavos africanos también trajeron con ellos sus idiomas, algunas palabras quedarían en la vida cotidiana constituyendo sus aportes lingüísticos. Fernando Romero publicó un diccionario muy completo sobre las voces usadas por los negros desde la Colonia hasta la República. ${ }^{56}$ Con mucha paciencia, recopiló información escrita sobre estos afronegrerismos tanto en el habla popular cotidiana como en la literatura. Muchas voces que se usan hoy en día y otras ya en desuso, tienen un pasado africano como: acanga, allanga, angú, bemba, borondanga, batán, bitute, bochinche, cajón, caramanduca, calanca, concolón, comba, cuco, curcuncho, chalona, chongo, chicote, lingo, mamarracho, maraca, ñato, ñoco, palangana, quimba, recute$\mathrm{cu}$, tacu-tacu, tunda, etc.

\section{La vestimenta}

En general, durante la Colonia y la República, los esclavos urbanos llevaban ropas que apenas cubrían las exigencias del clima y el pudor: calzones y calzoncillos, camisas y blusas, faldas y pantalones, ponchos, sombreros, medias, todo confeccionado con las telas más burdas como la bayeta y el sayal. Otros propietarios vestían elegantemente a sus esclavos con sus ropas usadas, de igual modo, algunas esclavas se vestían con la ropa desgastada de sus amas: saya y manto, guantes finos y zapatos delicados, tal como aparecen en las pinturas de Leonce Angrand y Maurice Rugendas. Muchas propietarias adornaban prolijamente a sus esclavos para que participen en las procesiones, dándoles incluso sus propias joyas para asombrar al público y a sus amistades. Por eso algunos viajeros describen a esclavas y libertas con joyas, saya y manto, y a esclavos con librea y guantes.

En las haciendas los propietarios trataban de invertir lo menos posible en los esclavos, la vestimenta era entregada una vez al año, así que es fácil imaginar que vestían esas ropas hasta que se convertían en harapos, porque no existía la noción de ropa de trabajo, para la casa y otra para dormir. Por otro lado, los jesuitas se preocupaban más en conservar su mano de obra, por eso los esclavos eran vestidos de acuerdo a la estación,

\footnotetext{
${ }^{55}$ Citado por Bowser, Frederick, 1977: pág. 45.

${ }^{56}$ Romero, Fernando. Quimba, fá, malambo, ñeque. Afronegrerismos en el Perú. Lima: IEP, 1981.
} 
ropa ligera de bayeta en el verano y de lana en el invierno, además entregaban ropa para los niños y los recién nacidos.

\section{La protesta de los esclavos}

\section{La protesta cotidiana}

La disconformidad con la esclavitud, el trabajo extenuante, la falta de alimentación, la ausencia de atención médica o la imposibilidad de contar con ropa adecuada, podían ser factores que desencadenasen diferentes actitudes en los esclavos como el trabajo a desgano, la vagancia ocasional, la destrucción de herramientas y utensilios, el chisme y la sátira. También se han identificado casos de deudas de jornales, refugio en la práctica religiosa intensa y los intentos de envenenar lentamente a sus amos. Unos pocos esclavos decidieron suicidarse o matar a sus hijos para escapar de la esclavitud.

Una estrategia cotidiana frecuente fue el legalismo. Casi todos los esclavos, sobre todo los urbanos, sabían el contenido de las leyes, sus derechos y límites, y teniendo cerca los tribunales acudían a pedir ayuda. Los esclavos rurales, más alejados, debían acudir al padrinazgo, buscar la figura protectora de un amo anterior, la esposa o la madre del propietario, el cura confesor, etc. sin embargo, a pesar de la lejanía, a veces se escapaban para llegar a los tribunales. También muchos esclavos, estando en el cepo, la panadería o fugitivos, hacían llegar sus peticiones a través de un familiar o amigo estableciendo redes de defensa muy eficientes.

\section{Rompiendo las normas}

\section{Cimarronaje}

El cimarronaje consistió en la fuga del esclavo. Fue una práctica utilizada por el esclavo desde los inicios de la vida colonial, prueba de ello es la Real Cédula de 1551 intentando erradicar esa costumbre con penas muy severas.
Durante la Colonia, un esclavo decidía fugarse por diversos motivos: falta de alimentación, atención médica o vestimenta, también cuando el trabajo era más pesado, debían dinero de los jornales y cuando recibían castigos. Otros fugaban cuando se les prohibía salir a visitar a los amigos, parientes, enamorados o esposos, incluso un esclavo caminó de Lima hasta Huacho sólo para ver a su enamorada quien había sido llevada hasta allí por el nuevo propietario. Algunas esclavas fugaban cuando estaban gestando o a punto de dar a luz para esconder al recién nacido. También algunos esclavos fugaron para ir a una fiesta, un bautizo, un cumpleaños, una procesión.

Algunos lograban evadir a sus amos por meses e incluso por años. En general, trataban de fugar disimuladamente, sin violencia, solos y casi siempre de noche. Pero a veces había excepciones, como sucedió el 4 de septiembre de 1634 cuando cuatro esclavos cimarrones tomaron por asalto un barco pesquero en el Callao, dominaron a dos guardias armados y dirigieron la nave rumbo al Norte. Dos semanas después, tres fugitivos fueron capturados en Santa pero uno se escapó y se perdió en las serranías. ${ }^{57}$

Una vez libre, el cimarrón se enfrentaba al problema de solucionar asuntos primordiales como alimentarse, vestirse, procurarse un cuarto o refugio. La gran mayoría se quedaba cerca de su lugar de residencia, algunas veces los esclavos del galpón o del barrio prestaban ayuda al fugitivo, en otras ocasiones los delataban. Otros buscaban refugio con sus familiares, las mujeres sobretodo, se escondían en casa de la mamá, los tíos, hermanos o esposos. Otros esclavos preferían esconderse en haciendas lejanas, en los callejones dentro de las ciudades o viajar a otros lugares más distantes, como Catalina Conga quien en 1610 caminó de Lima a Santa, o Josef Criollo quien huyó de Lima a México.

La gran mayoría de cimarrones regresaba, capturados o voluntariamente. Una forma de insertarse nuevamente, tal vez librándose del a

\footnotetext{
${ }^{57}$ Citado por Bowser, 1977: pág 245-246.
} 
castigo, era buscar previamente un padrino (el cura, un amo anterior, la esposa del amo, etc.) y acompañado de éste suplicar perdón al propietario. Ese fue el caso de Valeriana Lorente, esclava del cura de Corongo quien en 1791 fugó a Lima para asistir a las fiestas de Carnestolendas y luego regresó con su amo pidiéndole perdón, aduciendo que jamás se había fugado antes. ${ }^{58}$ Algunos tomaban la costumbre de huir para luego regresar pidiendo perdón, pero nuevamente fugarse. Los amos conocedores de esto, terminaban por aceptar la cimarronería, pero otros preferían venderlos declarando este vicio en la boleta de compra y venta.

Otros propietarios vendían los esclavos fugitivos antes de ser capturados. Era una transacción donde perdía el vendedor pues el valor de los esclavos disminuía ostensiblemente pero preferían no arriesgarse a perder totalmente. Además los costos de la captura y encarcelamiento los cubría el propietario.

Durante las primeras décadas del siglo XIX y hasta la abolición, la causalidad del cimarronaje parece ser el mismo: un quiebre en lo que debería ser la relación amo-esclavo, según el punto de vista de este último. Pero además aflora un factor más: la coyuntura independentista en la cual los bandos y proclamas prometían la libertad a los esclavos que peleasen por ellos. San Martín lo hizo antes de pisar territorio peruano y no pocos ilusionados se enrolaron, incluso durante el Protectorado. Uno de esos casos sucedió en la hacienda Santa Beatriz de Lima, donde 23 esclavos entre hombres, mujeres y muchachos, fugaron para servir a la Patria en 1821, según el propietario "salian y entraban sin querer trabajar...con arrogancia, insulto y desenfreno". 59

Desde fechas muy tempranas, el control del cimarronaje también fue un problema para los propietarios y para el Estado, tanto colonial como republicano. Al comienzo se intentó frenar este problema con leyes draconianas como la ordenanza de 1535 que fijaba la pena de muerte para el esclavo que fugaba por más de seis días. Para perseguirlos se nombraron alguaciles de campo en Lima, Nazca, Chancay e Ica pero al ser insuficientes, el Cabildo de Lima decidió otorgar esta responsabilidad al Alcalde Ordinario. La cacería de esclavos era un espectáculo: salían los jinetes acompañados de perros entrenados además de esclavos y libertos, éstos últimos usados por sus conocimientos de las costumbres y escondrijos de los fugitivos. En Lima empezaron a ofrecer recompensas por los cimarrones y bandoleros famosos, bastaba traer su cabeza o el cuerpo inerte.

La Gasca intentó reforzar las leyes existentes para amedrentar a los infractores: 100 azotes para el esclavo que huía por primera vez durante tres días; la castración o mutilación del pie para el que se ausentaba 10 días y mantenía relaciones sexuales con india o negra. En caso de veinte días o reincidentes, se imponía la pena de muerte. $\mathrm{Al}$ mismo tiempo se otorgaba recompensa a todo aquel que capturaba cimarrones y delincuentes. Las ordenanzas de La Gasca establecía que todo propietario debía denunciar a un esclavo huido, de lo contrario serían responsables de todos los gastos y daños causados. ${ }^{60}$

En 1557, el virrey de Cañete nombró a los dos primeros Alcaldes de la Hermandad para patrullar los alrededores de Lima. Estos tenían los mismos deberes que los Alcaldes Ordinarios en el medio rural: arrestar y capturar delincuentes de todo tipo, especialmente esclavos. En 1590, el mismo virrey ordenó el establecimiento de la Hermandad en todo el territorio colonial. El virrey Francisco de Toledo también se preocupó por controlar a los cimarrones, bandoleros y palenqueros: reiteró las normas durísimas del virrey Cañete, incluyendo la castración, y utilizó una red de espías, generalmente libertos y ex

\footnotetext{
${ }^{58}$ Archivo General de la Nación, Causas Civiles, Legajo 235, Cuaderno 2019, 1791.

${ }^{59}$ Archivo General de la Nación, Causas criminales, legajo 1, 1805-1824.

${ }^{60}$ Las Ordenanzas fueron dictadas el 1 de junio de 1549. Bowser, 1977: pág. 255.
} 
cimarrones. También repitió las ordenanzas sobre la prohibición a los españoles de esconder a los cimarrones para hacerlos trabajar a jornal, bajo pena de pagar 100 pesos la primera vez y con el destierro la segunda. Por el mismo delito, un indio noble sería rapado la primera vez y perdería su estatus la segunda, mientras que un indio común recibiría 200 azotes. Para libertos y esclavos que protegieran u ocultaran fugitivos, las penas eran de 100 azotes primero, luego la castración y la muerte si se hacía por segunda vez. ${ }^{61}$

La Hermandad funcionó con los Alcaldes quienes se rodearon de auxiliares, sobretodo esclavos y libertos al mando de un cuadrillero mayor. Fue usual capturar cimarrones con el fin de emplearlos como espías, quienes ingresaban a los montes y tomaban contacto con las bandas para luego informar al Alcalde la ubicación exacta de estos grupos.

En las primeras décadas del siglo XIX y durante las luchas de la independencia, las bandas de cimarrones y palenqueros seguían siendo un problema por resolver. Ante la situación anárquica la represión volvió a ser tan violenta como en los primeros tiempos coloniales. La pena de muerte se aplicó ampliamente a los bandoleros y cimarrones capturados si intentaban huir nuevamente o se resistían al arresto. Varios bandoleros famosos fueron aniquilados durante sus capturas, como Manuel Perales (a) "Chiquito", Manuel Masombrío, Ignacio Page, a quien aplastaron la cabeza con una piedra; "El Camanejo" fusilado en pleno monte, además de siete negros pertenecientes a una banda de nueve. ${ }^{62}$

Las ejecuciones de bandoleros atraían mucha gente y sus cadáveres eran expuestos en los lugares públicos, generalmente donde más robaban: edificios, haciendas, caminos, etc. En 1829, por ejemplo, el cadáver de "Animita" fue colgado frente a la Prefectura después de su ejecución. Anteriormente este célebre bandolero había rondado el mismo local policial burlándose de los custodios del orden. ${ }^{63}$

\section{Palenques}

El término palenque designaba un conjunto de huertos y chozas elaboradas toscamente por cimarrones, en algunos casos con construcción de empalizadas. Se puede afirmar que eran espacios liberados, aldeas autosuficientes de esclavos. En el Perú colonial los palenques no tuvieron tanta vigencia como en el Brasil o Colombia. En estos países los palenques dieron lugar a la posterior formación de pueblos. En el Perú los palenques fueron derrotados uno tras otro hasta quedar solo el nombre.

En un medio donde predominaba la pequeña y mediana propiedad, era muy difícil que un asentamiento humano de cimarrones pase desapercibido, además vivir de una agricultura incipiente tampoco era suficiente para cubrir las necesidades de alimentos. Por eso los palenques desarrollaron sus estrategias de supervivencia en torno a la agricultura, recolección de frutos, cestería, pesca, trabajo a jornal en las haciendas vecinas y el robo furtivo. Por ello elegían sitios con puquiales y cañaverales cercanos a las haciendas.

Uno de los palenques más numerosos parece que fue el de Huaura, formado en los tiempos del levantamiento de Gonzalo Pizarro. Más de 200 esclavos, entre hombre y mujeres, establecieron un palenque fortificado protegido por el pantano y los totorales de la zona. Poseían una organización y hasta tenían un rey nombrado por ellos mismos. Además, poseían algunas armas, como sables y arcabuces, arrebatadas a los españoles. Se decía que estos palenqueros tenían contactos con esclavos de Lima y con indígenas, quienes planeaban derrocar a los españoles para asumir el poder.

\footnotetext{
${ }^{61}$ Bowser, ibid. pág. 256-256.

${ }^{62}$ Citado por Aguirre, 1993: pág. 269.

${ }^{63}$ El Telégrafo. Lima, 13 de enero de 1829.
} 
Parece que la amenaza fue tan seria que Lorenzo de Aldana, encargado de gobernar Lima a nombre de Gonzalo Pizarro, dispuso una fuerza de 120 soldados al mando de Juan de Barbarán, antiguo conquistador y alcalde de la ciudad, para atacarlos. La batalla fue cuerpo a cuerpo, murieron 13 españoles, entre ellos el mismo Barbarán; también muchos esclavos quienes prefirieron morir a capitular. ${ }^{64}$

De allí en adelante durante toda la vida colonial, los palenques, afincados en toda la costa, se formaron por poco tiempo, sus miembros se dedicaban al robo furtivo, trabajo a jornal en las haciendas, la venta de caña y artículos robados, algunos incluso se desplazaban de las chacras a la ciudad pero ninguno se planteó modificar el sistema esclavista. Los palenques constituyeron una protesta limitada sin propuestas más allá del robo.

Algunos palenques, como el célebre Huachipa en Lima, lograron sobrevivir al margen de la ciudad, con una población permanente compuesta por hombres, mujeres y niños, todos libres. Al parecer vivían de algunas actividades simples: agricultura incipiente, elaboración de canastas, trabajo a jornal en las chacras cercanas y venta de caña en los tambos. Pero aún así constituían un desafío al sistema, por eso se organizaron cuadrillas para exterminarlos.

Ya para fines del siglo XVIII y comienzos del XIX, los palenques fueron decayendo. Sólo quedó el nombre para designar los lugares que servían de refugio a los bandoleros. Algunos palenques agrupados en bandas, actuaron al servicio de los montoneros en las luchas de independencia y posteriormente para los caudillos militares.

\section{Bandolerismo}

Muchos esclavos también se dedicaban al robo. Solos o en grupos, en las chacras o en las ciudades, obtenían ingresos adicionales, comida, vestimenta, dinero, etc.
Las bandas podían ser pequeñas, de 3 a 5 individuos, como también grandes, de 10 a 15 individuos. Las bandas en Piura estaban armadas con palos, cuchillos y armas de fuego, algunas oxidadas, pero que tenían un efecto persuasivo entre los viajeros y transeúntes. Algunas bandas estaban formadas solo por esclavos, otras por individuos de la misma casta, aunque también había bandas mixtas de libres y cautivos, negros, mestizos, indígenas, zambos y mulatos. Cabe resaltar que estaban formadas en su mayoría por hombres; las mujeres participaban encubriéndolos, vendiendo la mercadería robada, informando sobre las rondas, etc.

La mayoría de las bandas se formaban porque los individuos se conocían previamente en el lugar del trabajo la chacra, el convento, la panadería o porque eran parientes y amigos. Pero también hay casos en los cuales los miembros de una banda se conocían en la prisión. Incluso, algunos esclavos se incorporaron a la banda sin conocer a los bandoleros, sólo se enteraban que en determinado monte se escondían y se acercaban para engancharse.

Estas bandas robaban sin distinciones. Atacaban en los caminos, tambos, pulperías, tiendas, chinganas y casas; desvalijaban por igual a españoles, indígenas, comerciantes y pobres pescadores. Se trataba pues de una simple acción de supervivencia. Muchos empleaban la violencia, otros, por lo contrario, hacían gala de buenos modales. Uno de ellos fue el negro León quien solía pedir disculpas antes de tomar lo ajeno, incluso devolvió a un cura todo lo robado por sus compinches. Algunos bandoleros, cautivos y libres, solían usar capa, montaban caballo y usaban armas como los señores.

Los lugares más frecuentados por los bandoleros eran los caminos porque podían desvalijar a los transeúntes, viajeros, burócratas, comerciantes, pescadores y arrieros. Los tambos, pulperías, chinganas y chicherías también eran blancos favoritos porque encontraban lo necen-

\footnotetext{
${ }^{64}$ Citado por Bowser, 1977: pág. 243.
} 
sario para proveerse de artículos cotidianos. Las haciendas, chacras, casonas, callejones, tiendas, corrales y estancias también figuraban entre sus objetivos. El abigeato ocasional fue practicado para conseguir carne destinada para alimentarse o la venta. Las bandas actuaban en toda la costa: Trujillo, Zaña, Huacho, Huaura, Chancay, Pativilca, Lima, Cañete, Ica, Pisco, Chincha y Nazca. En Lima, estaban dentro de la ciudad y en los extramuros, especialmente en los caminos hacia el puerto y hacia el Sur, lugares donde se comercializaban las mercaderías. ${ }^{65}$

Para el siglo XIX, el bandolerismo ya era un problema endémico heredado de la Colonia. La coyuntura de la independencia lo revitalizó pues muchas partidas de bandoleros se enrolaron en los ejércitos, tanto realista como patriota, pero a la vez continuaban ejerciendo el bandolerismo.

Mientras en la Colonia había una tendencia hacia las bandas con integrantes de la misma casta, en el siglo XIX esa tendencia se desvaneció poco a poco. Esto lo demostró Carlos Aguirre al encontrar una composición multiétnica: casi el $90 \%$ de los integrantes pertenecían a grupos negros. $^{66}$

\section{Motines}

En el Perú colonial y republicano, los esclavos protagonizaron motines mayormente en las haciendas, mientras que en las ciudades el foco violento lo constituyeron las panaderías y las cárceles, paradójicamente, los lugares del control.

En las haciendas, los esclavos se encontraban bajo un ritmo de trabajo extenuante, frecuentes castigos del caporal o capataz, encerramiento en galpones, mala comida, escasa vestimenta, ausencia de medicinas, etc. Por otro lado, cuando los esclavos se casaban, algunos propietarios preferían restringir sus vidas sexuales solo al domingo, para evitarles desgaste físico. En el campo no había un tribunal que los escuche, a veces un cura intercedía, pero no todos tenían ánimo de protegerlos. Incluso algunos esclavos conocían qué hacendados eran más explotadores que otros.

Todos estas condiciones de vida esclava fueron la causa que hcieron estallar la violencia. Por lo general, los motines de esclavos estallaban cuando se rompía la normatividad de la relación amo-esclavo (el amo debe dar protección, alimentación, vivienda, vestido y medicinas al esclavo). También cuando se excedían los límites impuestos por la legislación pues los esclavos sabían cuántos azotes debían recibir por determinada trasgresión y aceptaban el castigo del amo, pero no el exceso.

La mayor parte de los motines no eran planificados, estallaban ante un pretexto puntual: los golpes del caporal, el encierro en el cepo, la amenaza de venderlos, etc. Una vez estallado el motín se incendiaba y destrozaba enseres, casas, sembríos, asesinaban a los agentes del control más próximos, como cuadrilleros, pero el blanco de la ira desatada eran el caporal, el propietario y su familia. Luego huían de la hacienda, se refugiaban en los campos, algunos regresaban después de vagar, yotros, muy pocos, establecían palenques.

Los casos de motines más conocidos fueron los que sucedieron en las haciendas de San Jacinto (1768), Motocachi (1786) y San José (1779), al norte de Lima. Los esclavos golpearon a los caporales y auxiliares, rompieron alacenas, sembríos, casa, herramientas, antes de darse a la fuga. Posteriormente, ya capturados confesaron que la causa era el maltrato, la escasa comida y el trabajo excesivo. Estos motines se dieron porque la Junta de Temporalidades cambió todo el sistema de los jesuitas. Los nuevos dueños o arrendatarios quitaron los incentivos, permisos, descansos, propinas, carne en la dieta, entre otros beneficios para el esclavo.

La causalidad de los motines continuó siendo la misma durante la República. Uno de los moti

\footnotetext{
${ }^{65}$ Arrelucea, Maribel, 1999: pág. 133.

${ }^{66}$ Aguirre, Carlos 1993: pag. 258.
} 


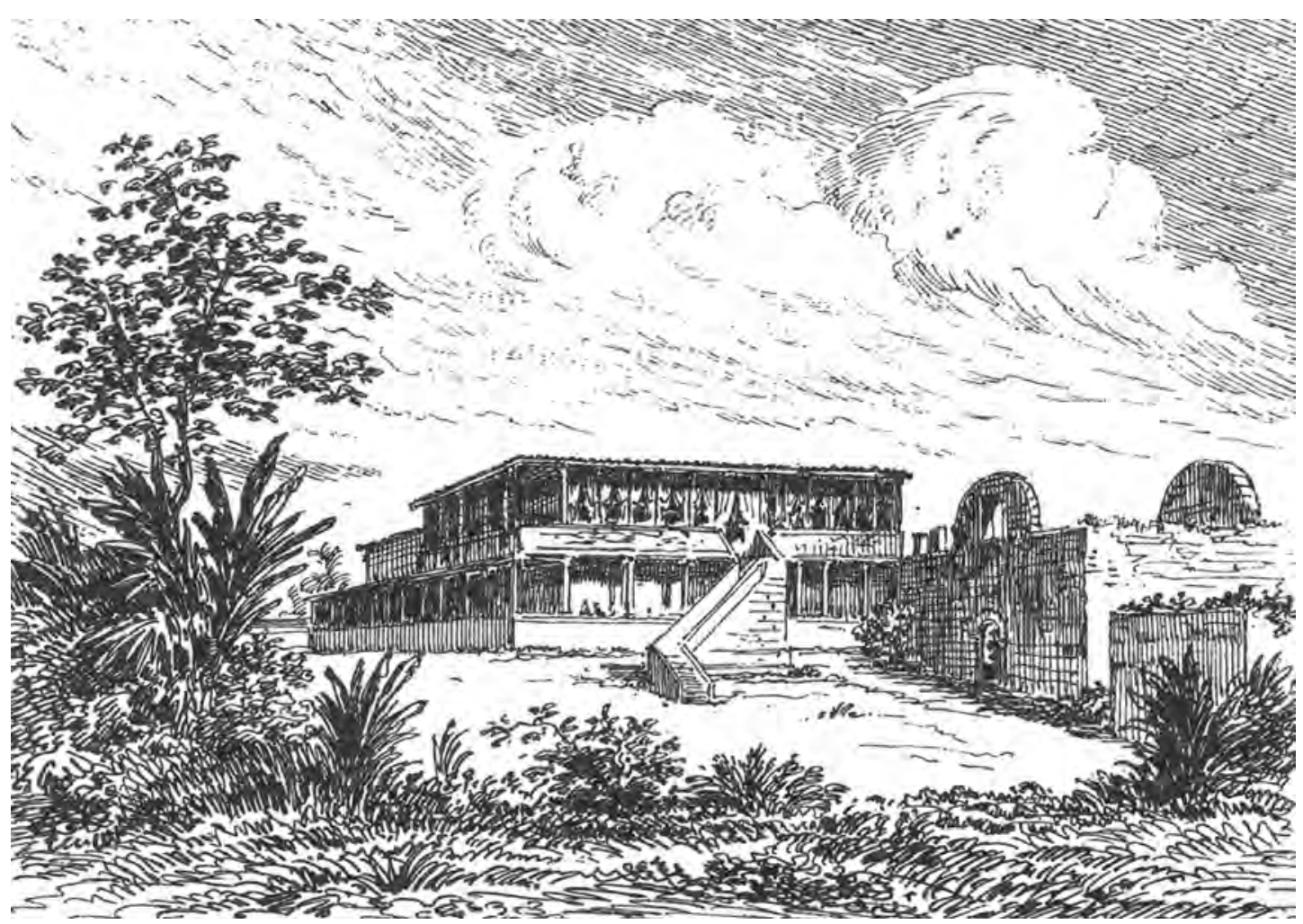

Hacienda San Pedro de Lurín. Uno de los típicos motines fue el protagonizado por los esclavos de esta hacienda en 1826. Grabado inserto en el libro Perú y Bolivia del viajero Charles Wiener.

nes típicos fue el protagonizado por los esclavos de la hacienda San Pedro de Lurín en 1826. Era una de las haciendas azucareras más grandes de Lima y la segunda más grande con mano de obra esclava. Un día, los esclavos capturaron al caporal y se enfrentaron al amo armados con piedras, para luego huir todos. Treinta esclavos, entre hombres y mujeres, fueron ante el Prefecto para quejarse y obtener perdón, mientras otros asaltaban en los caminos cercanos y vivían en los montes. Pocos días después fueron capturados. Posteriormente, en sus confesiones dirían que huyeron por los maltratos del mayordomo quien se encargaba de la hacienda en ausencia del amo. ${ }^{67}$

En 1805 sucedió un motín que resulta sorprendente. Unos 19 esclavos de la hacienda de los continuos azotes y el escaso alimento proporcionado por el arrendatario, salieron de la hacienda rumbo a Lima. Llegaron al palacio decididos a entrevistarse con el mismísimo virrey. Éste les prometió su ayuda mientras el tribunal expedía rápidamente una orden al propietario para que trate bien a sus esclavos. Pero, don Juan de Dios Barrionuevo, el propietario, no hizo caso al documento judicial y redobló los maltratos tomando represalias contra los esclavos. Unos días después, 28 esclavos marcharon a Palacio, se encadenaron al patio exigiendo el cambio inmediato de amo. Parece que así se hizo pues Barrionuevo tuvo un plazo de dos meses para vender sus instrumentos de labranza e irse de Pariachi. Al margen de sus reivindicaciones inmediatas (atacar al propietario no a la

${ }^{67}$ Aguirre, Carlos. "Paternalismo y rebelión en la hacienda esclavista en el siglo XIX, el caso de San Pedro", en Kuntur, 6, 1987. 
esclavitud como sistema), resulta sorprendente que se encadenen en el Palacio para lograr la intervención del mismo virrey. ${ }^{68}$

En las ciudades, los motines tienen el mismo perfil. Como las panaderías funcionaban con personal dedicado al control de los esclavos, siempre estaban vigilándolos $\mathrm{y}$, para mayor seguridad, los tenían encadenados, pero eso no era un impedimento para los motines que estallaban en cualquier momento. ${ }^{69}$

Los esclavos se sublevaban cuando les faltaba comida o atención médica (era frecuente que los obliguen a trabajar estando enfermos como al esclavo Juan, quien en 1791 trabajaba en el torno de una panadería estando con una hernia, y como no le hicieron caso, mató a un trabajador). Otros motivos eran por cuestiones sentimentales: se desesperaban al no saber de sus cónyuges o hijos.

Algunos esclavos no soportaban el castigo administrado en la panadería. Para librarse de las cadenas y escapar, recurrían a la automutilación. También hay casos de agresiones: algunas veces golpeaban y mataban a todo aquel que se les ponían al frente. Algunos lograban huir así, corrían por la calle, desesperados, hasta ser alcanzados y encadenados de nuevo. Estas escenas no eran raras en Lima.

Casi siempre los esclavos intentaban fugar solos y de noche. Pocas veces se unieron para planificar una fuga, como el caso de la panadería de Malambo en 1769. En la fuga participaron varias personas, entre hombres y mujeres, esclavos presos y aquellos que eran propiedad del panadero, aunque también estuvieron implicados jornaleros y el jardinero, todos indígenas, que laborabanallí.

Los esclavos presos planearon la fuga con anticipación, su único objetivo era huir lo más lejos posible. Con ese fin establecieron roles: el esclavo de la casa, un negro especialista en el torno llamado Juan Sebastián, fue el cabecilla y se encargó de coordinar con los otros presos. Dos esclavas de la panadería, María del Carmen y Gregoria recibieron el encargo de seducir al jardinero y a un jornalero para obtener dinero, herramientas y limas. La estrategia dio resultado. Durante la noche de Pascua, escucharon los ruidos de la celebración, esperaron pacientemente y cuando los vigilantes y el mismo jefe de sala se retiraron, abrieron un forado en la pared y fugaron. Previamente, destruyeron el torno recién adquirido por el panadero.

Al día siguiente comenzó la caza de los esclavos. Fueron capturados casi todos; otros regresaron solos y algunos buscaron a sus propietarios para suplicarles perdón. Resulta claro que estos esclavos solo pensaron en evadirse de las duras condiciones de trabajo y castigo correctivo pero no planificaron más allá, es decir, a dónde ir, cómo sobrevivir, etc. ${ }^{70}$ Este hecho demuestra la ausencia de una respuesta más contestataria en los esclavos urbanos quienes preferían usar las instancias legales, las diferentes formas de evasión y el pequeño cimarronaje, lo que podría llamarse la resistencia cotidiana.

\section{Los esclavos y las luchas por la independencia}

Las luchas por la independencia en Hispanoamérica coincidieron con la campaña inglesa para abolir la trata negrera y la esclavitud. Por ello los líderes de las revoluciones americanas adoptaron el tema dentro de sus discursos liberales. Así, tanto San Martín como Simón Bolívar dedicaron palabras conmovedoras contra este sistema esclavista, aunque detrás existía un interés práctico: necesitaban esos miles de hombres como soldados sumisos.

De esa manera, empezaron a plantear la abolición de la esclavitud. Riva Agüero propuson

\footnotetext{
${ }^{68}$ Agradezco al historiador Alejandro Reyes la comunicación personal sobre este caso.

${ }^{69}$ Estudios sobre panaderías en Aguirre, Carlos. "Violencia, castigo y control social, esclavos y panaderías en Lima, siglo XIX". Pasado y presente, 1, 1988; y Arrelucea, Maribel, "Conducta y control. Estudio de las panaderías limeñas, siglo XVIII". Revista del Archivo General de la Nación, 13, 1996.

${ }^{70}$ Arrelucea Maribel, 1999: pág. 180.
} 


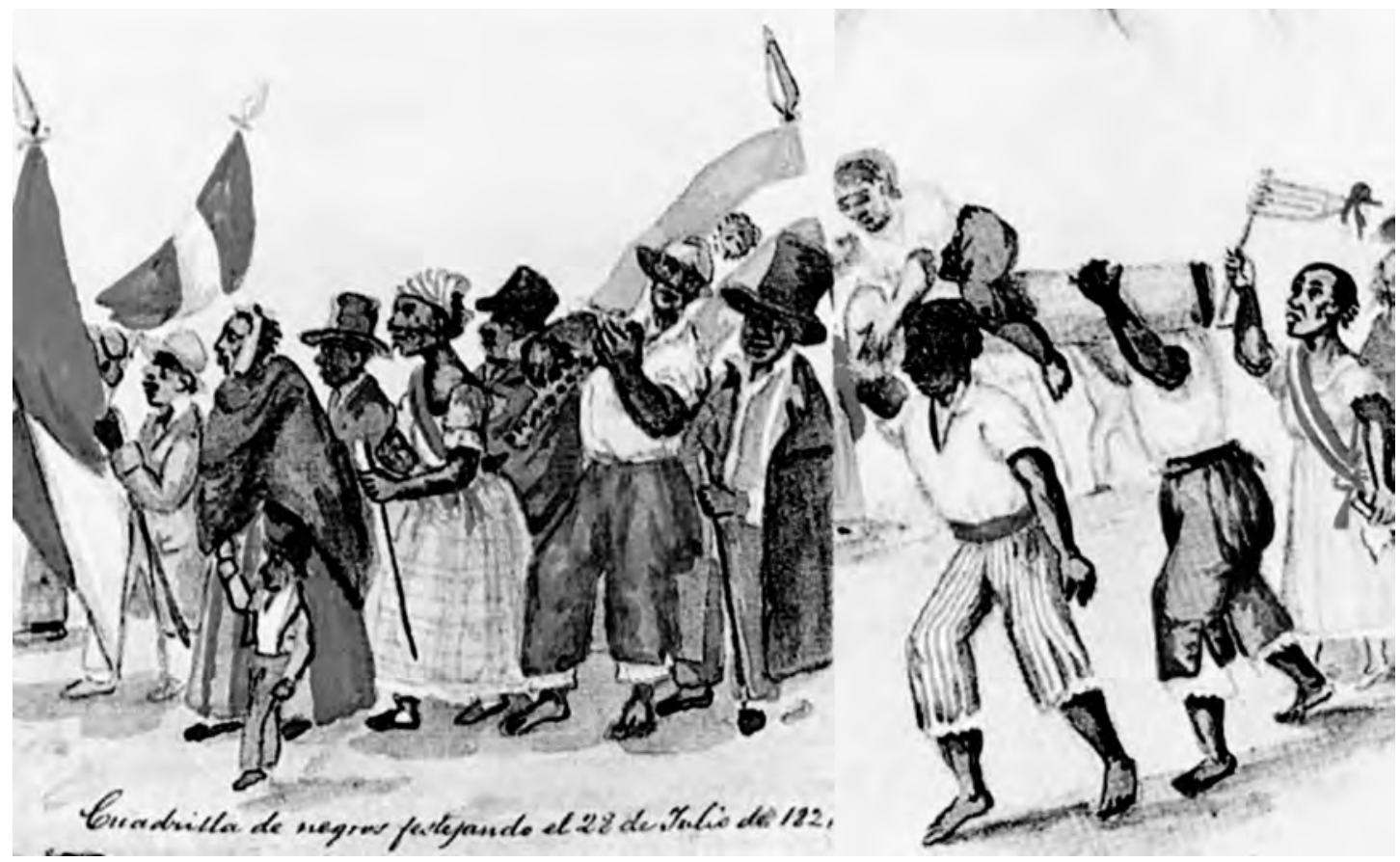

Negros limeños festejando la Independencia. Acuarela de Pancho Fierro.

liberar unos cuantos, los más hábiles, para que se encarguen de atraer a los esclavos de haciendas y apoyar a San Martín. Cuando el libertador del sur arribó a nuestras costas lo hizo con proclamas prometiendo la libertad a todo esclavo que pelease en sus filas. Muchos esclavos, entusiasmados y crédulos, se enrolaron como milicianos y montoneros. Pero una vez proclamada la independencia y establecido el Protectorado, San Martín dicta el bando de libertad de vientres: todos los hijos de esclavos nacidos a partir del 28 de julio de 1821 serían libres. Unos días después, dicta otro bando dando la libertad a todos los esclavos de españoles emigrados y, posteriormente, ordena que todos los libertos beneficiados por la ley de Libertad de Vientres debían quedar sujetos al patronato de sus madres hasta los 20 años, en las mujeres, y 24 años en los hombres.

En la práctica, la esclavitud continuó en el Perú, así como las duras condiciones de vida y escasas oportunidades de sobrevivir que encontraba un marginal en la sociedad colonial y republicana.
Bolívar, por su parte, tratando de obtener más soldados, ordenó en 1824 que los esclavos tenían derecho a solicitar variación de amo sin más causal que su voluntad. Pero en 1825 apareció el Reglamento Interior de las Haciendas de la Costa en el cual se ordena el tiempo de trabajo, castigos, derechos de los esclavos, etc. Esta fue una reacción de parte de los hacendados, preocupados por el avance de la campaña inglesa, la especulación delos precios y el encarecimiento de los esclavos.

Durante las guerras de independencia el bandolerismo asumió características políticas porque no se trató de una guerra entre dos grandes ejércitos profesionales, sino más bien entre diversos actores y grupos: soldados formales de los batallones y milicias, montoneros y los "vándalos”. Por supuesto que un soldado en algún momento se convertía en vándalo y un vándalo en miliciano. Las confusiones son muchas por la ambigüedad en los mismos protagonistas. Asimismo, el discurso racista también estuvo bien presente cuando se trataba de opinar sobre los montoneros. Vidaurre decía "son indios, 
negros, personas estúpidas, que oyen la voz de la naturaleza que impele a la defensa de los derechos". Igual opinaba un escritor del periódico El Limeño cuando en 1834 afirmaba: "como si el grito del ebrio, el asesino, del vago, del esclavo, de los seres más despreciables fuese conforme a los sentimientos de los peruanos". ${ }^{71}$

Por otro lado, las luchas por la independencia rompieron buena parte de la estructura colonial. Muchas bandas de cimarrones crecieron en número y algunas llegaron a integrarse con bandoleros de diferentes castas y con los montoneros. Como bien opinó Hünefeldt ${ }^{72}$, constituyeron una fuerza constante y peligrosa, además de inestable. Varios jefes montoneros intentaron incorporarlos en sus filas como Miller y Francisco Paula Otero. Algunas montoneras, respaldadas por cimarrones y bandoleros, tuvieron tal éxito que cortaban el suministro de alimentos y pertrechos de guerra a Lima.

Sin embargo, todos sus esfuerzos en pos de un concepto abstracto, como era la libertad republicana, se esfumaron pues los líderes de las guerras y los caudillos militares que llegaron restablecieron los lazos esclavistas. En 1830 se dispuso que un liberto sería considerado así a partir de los 30 años; en 1831 se derogó el decreto de Bolívar; en 1839 la Constitución de Huancayo alargó el plazo a los libertos hasta los 50 años de edad para ser considerados como tales.

Mientras Inglaterra presionaba por anular la trata de esclavos, en el Perú, por lo contrario, muchos alzaron sus voces para defender esta institución. Uno de ellos fue José Gregorio y Paz Soldán quien escribió Memoria sobre la esclavatura en el Perú en 1846. En este texto Paz Soldán afirma que el tratamiento que se daba a los esclavos en el Perú era más suave y los hacía dichosos. Los esclavos agrícolas, decía, trabajaban ocho horas diarias como máximo, y como el trabajo se distribuía por tareas, quien terminaba más rápido, podía pedir más tareas y cobrar como jornalero libre. También subrayó la práctica de otorgarles chacras, dejarlos criar animales para su consumo o venta y obtener dinero extra cortando pasto, fabricar canastas, cortando y vendiendo leña del monte. La intención de este autor era mostrar lo benigno de la esclavitud peruana. Según él, todos los esclavos eran tan bien tratados que no había necesidad de abolir la trata de esclavos y el sistema en sí.

De igual opinión era Juan Bautista Lavalle, quien mostró su hacienda limeña a su ilustre visitante, Flora Tristán. Después de ver la casa pasaron a los depósitos de esclavos y el cuarto de castigo donde Flora, horrorizada, observó a dos esclavas castigadas en el cepo porque habían asesinado a sus propios hijos. El hacendado calmadamente le dijo que "la esclavitud aquí, como entre todos los pueblos de origen español, es más dulce que entre las demás naciones de América" para añadir luego que "es desgraciadamente demasiado cierto que no se les puede hacer marchar sino con fuete". Ella replicaría posteriormente que en las condiciones de vida de esas dos infelices, también habría hecholomismo. ${ }^{73}$

\section{La abolición de la esclavitud}

La abolición de la esclavitud en las colonias hispanas fue un proceso lento, dada en diferentes fechas, y sustentada en un discurso liberal muy débil.

La abolición del tráfico abominable por la Corona inglesa en 1807 fue el paso fundamental, pues se asoció con los principios liberales durante la coyuntura independentista que sacudía las colonias hispanoamericanas. Las primeras Juntas de Gobierno incluyeron el tema: la aboli-

\footnotetext{
${ }^{71}$ Citado por Walker, Charles. "Montoneros, bandoleros, malhechores: criminalidad y política en las primeras décadas republicanas", en Bandoleros, abigeos y montoneros. Criminalidad y violencia en el Perú, siglos XVI-XX. Aguirre y Walker (ed.) 1990.

${ }^{72}$ Hünefeldt, Christine. “Cimarrones, bandoleros, milicianos: 1821”. Histórica, vol. III, 2, 1979.

${ }^{73}$ Tristán Flora. Peregrinaciones de una paria. Lima: Librería Studium, 1986, pág. 298.
} 
ción fue declarada por la Suprema Junta de Caracas en 1810; Hidalgo la declaró en México el mismo año. El Congreso chileno siguió el ejemplo en 1811, y al año siguiente el gobierno de Buenos Aires hizo lo mismo. Incluso el discurso abolicionista también se escuchó en las Cortes de Cádiz pero finalmente, no fue incluida.

Inglaterra declaró la trata esclavista como ilegal, los barcos negreros fueron confiscados y los esclavos liberados. Los buques ingleses interceptaban barcos negreros en todos los mares, perseguía contrabandistas y los juzgaba bajo el cargo de piratería en una corte especialmente creada con este fin. Sin embargo, los precios se dispararon porque la demanda continuaba siendo fuerte y seguían llegando esclavos.

Inglaterra empleó toda su habilidad diplomática y hasta las presiones económicas y políticas para conseguir la anuencia de las nuevas repúblicas. En 1839, el dictador Rosas prohibió definitivamente la trata en Argentina, Venezuela lo hizo en el mismo año, mientras que en México se firmó en 1842. En Chile, prácticamente ya no había esclavos desde 1823, año de la manumisión pero firmó el tratado con Inglaterra en 1842, Ecuador lo hizo en 1847 y Colombia en 1851. Más tardíos fueron Puerto Rico (1873) y Cuba (1880) lugares donde la esclavitud era una institución de primera importancia.

En el caso del Perú, la abolición también fue tardía ¿Cómo se explica esto? Algunos contemporáneos de Ramón Castilla, como Santiago Távara y Manuel Labarthe, construyeron un marco ideológico para sustentar la abolición mencionando que ya había un discurso liberal, con campañas auspiciadas por Pedro Gálvez y Manuel Toribio Ureta. ${ }^{74}$ Pero no existen discursos o artículos que prueben esta campaña. Por eso es mejor observar los acontecimientos previos.

El 18 de noviembre de 1854, el presidente Echenique dispuso que todo esclavo doméstico o de hacienda que se presentase al servicio del ejército obtendría su libertad por este solo hecho, y la gracia se haría extensiva a su mujer legítima. La única condición exigida era un servicio de dos años como mínimo. Además se entregaría una indemnización al amo para evitar reclamos posteriores.

$\mathrm{Al}$ enterarse del respaldo de muchos propietarios y esclavos a Echenique, Castilla, desde su cuartel general en Huancayo y en plena guerra civil contra el Presidente, dio el Decreto del 3 de diciembre de 1854 aboliendo la esclavitud en todo el territorio de la República. Solo excluía del derecho de libertad a los que estaban en las filas de Echenique. El Decreto mencionaba claramente que los propietarios recibirían una indemnización justa.

Posteriormente, el 23 de enero de 1855, acabada la guerra y derrotado Echenique, Castilla dio otro Decreto que complementaba el anterior. Se obligaba a los esclavos a trabajar durante tres meses en las haciendas a cambio de un jornal, igualmente el amo podía expulsar a sus esclavos improductivos mientras que los esclavos domésticos fueron obligados a permanecer hasta por ocho días en casa de sus amos. Además todo esclavo desocupado sería tratado como vago y encarcelado. En suma, tal Decreto buscaba un paso gradual de la esclavitud a la libertad salvando los intereses de los propietarios.

Poco después, el 9 de marzo de 1855, otro Decreto reglamentó el tema de las indemnizaciones a los propietarios fijándose el precio de 300 pesos por cada esclavo sin distinción de sexo, edad, condiciones físicas, etc. Se ha señalado que esta indemnización fue excesiva al contrastarla con los precios de otros sitios como las colonias inglesas donde era 60 pesos, en Honduras fue 265 pesos, en Nueva Granada fue de 74 pesos, etc. Carlos Aguirre ha señalado que ese era el precio promedio de venta de los esclaa-

\footnotetext{
${ }^{74}$ Távara, Santiago, Abolición de la esclavitud en el Perú, Lima: imprenta del Comercio, 1855; Labarthe, Manuel "La evolución del régimen jurídico de la esclavitud en el Perú". Separata de la Revista del Foro, XLII, 2, 1955.
} 
vos en el mercado limeño en ese momento. Pero este proceso también estuvo plagado de fraudes, Ricardo Palma sostenía que se pagó por 25,505 esclavos cuando en 1854 solo existían algo de 17,000. Por su parte, Alfonso Quiroz ha demostrado que este proceso benefició a los hacendados quienes inyectaron nuevos capitales a la agricultura y reforzaron sus vínculos con el capital comercial.

\section{Después de la Abolición}

Si bien los esclavos fueron libres gracias a una decisión oportunista de Castilla, la nueva situación no parecía ser diferente a la anterior. Los esclavos rurales continuaron en el campo, otros se desplazaron lejos. En las ciudades muchos fueron arrojados a la calle por estar enfermos, tullidos, etc. Otros se marcharon en busca de trabajo mientras que algunos permanecieron con sus ex amos.

Al parecer la abolición sorprendió a muchos esclavos y no la entendieron a cabalidad. Acostumbrados a permanecer en las haciendas, donde podían disponer de una chacrita, animales y choza, de pronto eran expulsados. Algunos se resistieron, como Cipriano y Blasa, esclavos de la chacra de San Miguel en Lima. El domingo recibieron su propina y salieron a pasear, pero al regresar el mayordomo les dijo que se lleven sus animales y enseres porque eran libres. Los expulsó. Ellos sintieron un desamparo total, debían empezar a construir una vida libre que implicaba también responsabilidades. Al intentar regresar a la chacra, discutieron con el mayordomo y lo mataron. ${ }^{75}$

Para otros esclavos, la abolición no fue tan difícil. Sobre todo para aquellos que tenían un oficio, eran jóvenes y sanos, suficiente como para negociar nuevas alternativas y mantener sus niveles de vida. La mayor parte de los ex esclavos permanecieron bajo el dominio de sus ex amos.
Según el discurso liberal debía establecerse una nueva relación laboral basada en el salario. Pero en la práctica, si bien la compra y venta de esclavos desapareció, las relaciones siguieron siendo serviles, muchos esclavos siguieron trabajando en las haciendas bajo la atenta mirada del caporal, viviendo en los mismos galpones y comiendo lo mismo. Y esto fue porque la élite peruana no había cambiado, seguía pensando que la mejor manera de obtener ganancias era usando esclavos, de allí que ante la abolición definitiva de la esclavitud buscaran una alternativa similar: importar coolíes chinos. Incluso el mapa de distribución de la población negra no sufrió grandes alteraciones, pues continuaron habitando Piura, Zaña, Cañete, Lima, Ica, Chincha, Pisco y Nazca.

\section{Bibliografía}

Adanaqué, Raúl

1991 "Condiciones de vida de los esclavos en el Perú". El Peruano.

1991 "Marcas y castas de esclavos en el Perú". El Peruano.

1991 "Marcas y castigos de esclavos en el Perú”, El Peruano.

1993 "Cofradías de esclavos en el Perú colonial”. La Mañana.

1993 "Marcas de esclavos en el Perú". La Mañana.

Aguirre, Carlos

1987 "Paternalismo y rebelión en la hacienda esclavista. ElcasoSan Pedro". Kuntur, 6.

1987 "Violencia y control social, esclavos y panaderías en el siglo XIX”. Pasado y Presente, 1.

1990 Agentes de su propia libertad. Los esclavos de Lima y la desintegración de la esclavitud. Lima: PUCP.

\footnotetext{
${ }^{75}$ Citado por Aguirre, 1993: pág 313.
} 
Aguirre, Carlos; Ballumbrosio, Eusebio; Delgado, Luis (et al.)

2000 Lo africano en la cultura criolla. Lima: Fondo Editorial del Congreso del Perú.

Arrelucea, Maribel

1996 "Conducta y control social colonial. Estudio de las panaderías limeñas". Revista del Archivo General de la Nación, 13.

1998 "De bandoleros y curanderos: opciones del cimarronaje en la costa central". Revista del Archivo General de la Nación, 16.

1999 "Conducta social de los esclavos de Lima, 1760-1820”. Tesis de Licenciatura, Lima: UNMSM.

2001 "De la pasividad a la violencia. Las manifestaciones de protesta de los esclavos limeños, 1760-1820". Historia y cultura, 24.

Bowser, Frederick

1975 "The free person of color in Lima and Mexico City: Manumission and opportunity". En Engerman y Genovese ed. Race and Slavery in the Western Hemisphere. Princeton: Princeton University Press.

1977 El esclavo africano en el Perú colonial, 1524-1650. Barcelona: Siglo XXI. ed.

Cajavilca, Luis

1939 La esclavitud en la hacienda San Francisco de Borja de Tumán, ss. XVI-XVIII. Lima: UNMSM.

Espinoza, Victoria

1988 "Cimarronaje y palenques en la costa central del Perú: 1700-1815”. Primer Seminario sobre Poblaciones Inmigrantes, vol. II.

Flores Galindo, Alberto

1984 Aristocracia y plebe. Lima 1760-1830. Lima: Mosca Azul.

Hart-Terre, Emilio y Marquez Abanto, Alberto

1963 "El artesano negro en la arquitectura virreinal limeña". Revista del Archivo Nacional, XXVI.
Huertas, Lorenzo

1988 "Esclavitud y economía regional: Huamanga, 1577-1855". Primer Seminario sobre Poblaciones Inmigrantes, vol. I.

Hünefeldt, Christine

1979a "Los negros de Lima”. Histórica, III, 1.

1979b "Cimarrones, bandoleros, milicianos". Histórica, III, 2.

1987 Mujeres, esclavitud, emociones y libertad. Lima: IEP.

1988 "Jornales y esclavitud. Lima en la primera mitad del siglo XIX”. Economía, X, 9.

1992 Lasmanuelos. Vida cotidiana de una familia negra en la Lima del siglo XIX. Lima: IEP.

Kapsoli, Wilfredo

1975 Sublevaciones de esclavos en el Perú. Siglo XVIII. Lima: Universidad Ricardo Palma.

Klein, Herbert

1986 La esclavitud africana en América Latina y el Caribe. Madrid: Alianza editorial.

Labarthe, Manuel

1955 "La evolución del régimen jurídico de la esclavitud en el Perú". Separata de la Revista del Foro, XLII, 2.

López Albújar, Enrique

1936 Los caballeros del delito. Lima: Ed, Juan Mejía Baca.

Mac Lean y Estenos, Roberto

1948 Los negros en el nuevo mundo. Lima: PTCM.

Macera, Pablo

1975 Trabajos de historia. Lima: INC, III vol.

Mejia, Yolanda

"Las panaderías coloniales del siglo XVIII". Sequilao, III, 4.

O'Phelan, Scarlett (comp.)

2003 Etnicidad y discriminación racial en la historia del Perú. Lima: PUCP, Instituto Riva Agüero, Banco Mundial.

Palma, Ricardo

1997 Anales de la Inquisición de Lima. Lima: Ediciones del Congreso de la República. 
Price, Richard (comp.)

1981 Sociedades cimarronas. Comunidades esclavas rebeldes en las Américas. México: Siglo XXI.

Quiroz, Francisco

1997 Un palenque llamado Lima”. Alma Mater.

Reyes, Alejandro

1985 Esclavitud en Lima, 1800-1840. Lima: UNMSM.

1987 "Pariachi, la rebelión de los esclavos y la toma de Palacio".

Romero, Fernando

1981 Quimba, fa, malambo, ñeque. Afronegrerismos en elPerú. Lima: IEP.

1992 Safari africano y compraventas de esclavos para el Perú. Lima: IEP.

Tardieu, Jean

1997 El esclavo en el Cusco. Lima: PUCP.

Távara, Santiago

1855 Abolición de la esclavitud en el Perú, Lima: imprenta del Comercio.

Tord, Javier y Carlos Lazo

1977 Del negro señorial al negro bandolero. Cimarronaje y palenques en Lima, siglo XVIII. Lima: BPHES.

1980 "Economía y sociedad en el Perú colonial", en Historia del Perú, Juan Mejía Baca ed. vol. IV y V.

1981 Hacienda, fiscalidad y luchas sociales, Perú colonial. Lima: BPHES.

Trazegnies, Fernando

1981 Ciriaco de Urtecho, litigante por amor. Lima : PUCP.
Tristán, Flora

1986 Peregrinaciones de una paria. Lima: Librería Studium.

Varallanos, José

1936 Bandoleros en el Perú. Ensayos. Lima: Altura.

Vega, Walter

1997 "Cofradías en el Perú colonial: una aproximación bibliográfica”. Diálogos, 1 .

Vegas, Ileana

1996 Economía rural y estructura social en las haciendas de Lima durante el siglo XVIII. Lima: PUCP.

Velázquez, Marcel

2002 El revés del marfil. Género, etnicidad y modernidad. Lima: UNFV.

Vivanco, Carmen

1981 El bandolerismo en el Perú. 1760-1819. Lima: BPHES.

Walker, Charles y Carlos Aguirre(ed.)

1987 Bandoleros, abigeos y montoneros. Criminalidad y violencia en el Perú. Lima: Instituto de Apoyo Agrario / Pasado y Presente.

Wiener, Charles

1993 Perú y Bolivia, relato de viaje. Lima: UNMSM.

\section{Zapata, Roger}

1990 Imágenes de la resistencia indígena y esclava. Lima: Wari. 